\title{
ARTYKUŁY
}

Zbigniew Domżał

Andrzej Wałkówski

Łódź

\section{Z badań nad piśmiennictwem sakralnym średniowiecznej biblioteki klasztoru cystersów w Mogile}

Skryptoria i piśmiennictwo cystersów należą obecnie do lepiej poznanych dziedzin. Jest to najprawdopodobniej wynik badań grona uczonych, także skupionych wokół wyspecjalizowanych placówek, takich jak np. Zespół do Badań nad Historią i Kulturą Cystersów przy Instytucie Historii Uniwersytetu im. Adama Mickiewicza, i realizacji postulatu Kazimierza Bobowskiego z początku lat 90. XX w. ${ }^{1}$ objęcia tej problematyki kompleksowymi badaniami przez polską naukę historyczną. Cystersi filiacji portyjskiej doczekali się opracowania ich skryptoriów do końca XIII w. na Śląsku² i w Małopolsce (Mogiła) ${ }^{3}$. Trzeba przy tym dodać, że w drugim przypadku badania kontynuowano - doprowadzono je do początków XVI wieku4 . Księgozbiorem i skryptorium klasztoru cystersów w Lubiążu zajmował się także Konstanty Klemens Jażdżewski .

Badania nad biblioteką i piśmiennictwem cystersów z klasztoru w Mogile prowadziła już Hanna Kuna, która m.in. wskazała na doskonałą znajomość księgozbioru, jaką posiadał kronikarz klasztorny Mikołaj z Krakowa oraz na wysoką ocenę dorobku Tomasza z Akwinu u cystersów z Mogiły ${ }^{6}$. Edward

\footnotetext{
K. Bobowski, O potrzebie badań nad skryptoriami dokumentowymi cystersów na ziemiach polskich w okresie średniowiecza. Stan i propozycje metod badawczych, [w:] Cystersi w kulturze średniowiecznej Europy, red. J. Strzelczyk, Poznań 1992, s. 57.

2 A. Wałkówski, Skryptoria cystersów filiacji portyjskiej na Śląsku do końca XIII wieku, Zielona Góra-Wrocław 1996.

3 Tenże, Skryptorium klasztoru cystersów w Mogile do końca XIII wieku, Łódź 2009.

4 Z. Domżał, A. Wałkówski, Imię róży inaczej...W tajemniczym świecie pisarzy i rękopisów klasztoru cystersów w Mogile do początków XVI wieku, Łódź 2016.

5 K.K. Jażdżewski, Lubiąż. Losy i kultura umystowa śląskiego opactwa cystersów (1163-1642), Wrocław 1992, s. 119-242.

6 H. Kuna, Z dziejów biblioteki OO. Cystersów w Mogile od jej założenia do początku XVIII wieku, „Rocznik Naukowo-Dydaktyczny. WSP w Krakowie. Prace Bibliotekoznawcze” 1984, nr 2 (89), s. 48, 50-51.
} 
Potkowski odnotował straty w bibliotece konwentu spowodowane pożarem w 1447 r. $^{7}$ Bibliotekami cysterskimi interesował się także Rafał Witkowski, który podkreśla1, że wysoką pozycję zajmowała w nich literatura patrystycz$\mathrm{na}^{8}$, a od XV stulecia nastąpił znaczny wzrost liczby książek ${ }^{9}$.

Jak wyżej wspomniano widoczny wzrost produkcji piśmienniczej przypada na wiek $X^{10}$. Tym samym narasta potrzeba dokonania jej segregacji i systematyzacji. Tymczasem średniowieczna literatura i nauka nie dają się podzielić według współczesnych kryteriów, a ówczesne granice między poszczególnymi działami wiedzy są z dzisiejszego punktu widzenia mało precyzyjne ${ }^{11}$. Zachodzi konieczność stworzenia kryteriów podziału średniowiecznego piśmiennictwa. Podstawę do tego mogą stanowić poglądy E. Potkowskiego. Wyróżnił on dwie główne funkcje pisma w średniowieczu - piśmienność sakralną i pragmatyczną ${ }^{12}$. Ten drugi termin oznaczał praktyczne wykorzystanie pisma w życiu codziennym, przy czym użytkownikami byli tu nie tylko duchowni, lecz także świeccy ${ }^{13}$. Tym samym pochodną funkcji pragmatycznej pisma będzie związana z nią cała grupa dzieł nazywana piśmiennictwem pragmatycznym ${ }^{14}$, a niekiedy praktycznym" ${ }^{15}$. Natomiast piśmienność sakralna oznaczała wykorzystanie pisma w realizacji zasad

7 E. Potkowski, Książka rękopiśmienna w kulturze Polski średniowiecznej, Warszawa 1984, s. 124 , przyp. 5 .

8 R. Witkowski, Biblioteki klasztorne opactw cysterskich na ziemiach polskich i dawnej Rzeczypospolitej. Zarys problematyki i stan badań, [w:] Monasticon Cisterciense Poloniae, t. 1: Dzieje i kultura męskich klasztorów cysterskich na ziemiach polskich i dawnej Rzeczypospolitej od średniowiecza do czasów wspótczesnych, red. A.M. Wyrwa, J. Strzelczyk, K. Kaczmarek, Poznań 1999, s. 156.

9 Tenże, „Ars scribendi” $w$ opactwach cysterskich na Pomorzu w średniowieczu, [w:] Biblioteki i skryptoria cysterskie na Pomorzu. Pelplin 23-25 maja 2008, red. A. Słyszewska, ks. A. Nadolny, A. Wałkówski, Pelplin 2010, s. 27-28.

10 Tamże.

11 S. Rybandt, Średniowieczne opactwo cystersów w Rudach, Wrocław 1977, s. 129.

12 E. Potkowski, Książka i pismo w średniowieczu. Studia z dziejów kultury piśmiennej i komunikacji spolecznej, Pułtusk 2006, s. 24, 26-27, 32.

13 Tenże, Pragmatyczna piśmienność w średniowiecznym Tyńcu, [w:] Benedyktyni tynieccy w średniowieczu, red. K. Żurowska, Kraków 1995, s. 80.

14 A. Wałkówski, Piśmiennictwo pragmatyczne skryptoriów cystersów filiacji portyjskiej na Ślasku do końca XIII wieku, „Acta Universitatis Wratislaviensis. Historia” 2001, nr 152, s. 87-91; tenże, Biblioteka klasztorna jako miejsce pracy średniowiecznego uczonego. Rozważania na tle badań piśmiennictwa cystersów, ABMK 2005, t. 83, s. 128-134.

15 E. Gigilewicz, Pojęcie „piśmiennictwo pragmatyczne”. Rozważania leksykograficzne, [w:] Piśmiennictwo pragmatyczne w Polsce do końca XVIII wieku na tle powszechnym, red. J. Gancewski, A. Wałkówski, Olsztyn 2006, s. 31. Krzysztof Skupieński zaproponował pojęcie piśmienności praktycznej - zob. tenże, $O$ współudziale dyplomatyki w badaniu piśmiennej warstwy polskiego spoleczeństwa średniowiecznego, [w:] „Venerabiles, nobiles et honesti”. Studia z dziejów społeczeństwa Polski średniowiecznej. Prace ofiarowane Profesorowi Januszowi Bieniakowi w siedemdziesiąta rocznicę urodzin i czterdziestopięciolecie pracy naukowej, red. nauk. A. Radzimiński, A. Supruniuk, J. Wroniszewski, Toruń 1997, s. 537, przyp. 41. 
ewangelicznych i wyrażania chwały Bożej w całym szeregu służących do tego dzieł z Biblią na czele ${ }^{16}$. Te teksty można określić mianem piśmiennictwa sakralnego, umożliwiającego człowiekowi nawiązanie kontaktu z Bogiem, ułatwiającego praktyki religijne publiczne i prywatne, nauczanie zasad wiary $\mathrm{i}$ jej pogłębienie ${ }^{17}$. Termin ten w praktyce jest dość szeroki, ponieważ stosujemy go do dzieł kierujących myśli człowieka ku Bogu, a kategoria ta funkcjonuje już od początków chrześcijaństwa (wskazuje ona zarazem na religijny sens ludzkiej egzystencji) ${ }^{18}$. W niniejszym artykule zajmiemy się tylko aspektem sakralnym piśmiennictwa obecnego w spuściźnie dawnej, średniowiecznej biblioteki klasztoru cystersów w Mogile.

Badaniami objęto 20 kodeksów. $\mathrm{Z}$ tego 14 zostało przebadanych bezpośrednio, ponieważ tylko te zostały nam udostępnione ${ }^{19}$, zaś sześć przebadaliśmy jedynie w oparciu o w oparciu o Katalog Archiwum ... Kazimierza Kaczmarczyka i Gerarda Kowalskiego ${ }^{20}$, gdyż z powodu remontu w archiwum klasztoru cystersów w Mogile były one niedostępne. Większość kodeksów pochodzi z XV w., przy czym tylko dwa z jego pierwszej połowy ${ }^{21}, 11-\mathrm{z}$ połowy stulecia ${ }^{22}$, a siedem $-\mathrm{z}$ drugiego pięćdziesięciolecia ${ }^{23}$. Liczebnie przeważają zatem rękopisy od połowy XV w. - zachowało się ich 18. Zdaniem E. Potkowskiego ten stan jest spowodowany stratami powstałymi w księgozbiorze w wyniku pożaru z $1447 \mathrm{r} .{ }^{24}$ Odbudowa biblioteki po pożarze była czyn-

16 E. Potkowski, Książka i pismo w średniowieczu..., s. 12.

17 A. Wałkówski, Biblioteka klasztorna jako miejsce..., s. 118; tenże, Piśmiennictwo sakralne skryptoriów klasztorów cysterskich w Lubiążu i Henrykowie do końca XIII wieku, [w:] Cystersi w społeczeństwie Europy Środkowej, red. A.M. Wyrwa, J. Dobosz, Poznań 2000, s. 378-390; por. E. Potkowski, Książka w kręgu sacrum - przykład Irlandii we wczesnym średniowieczu, „Przegląd Humanistyczny” 1996, r. 40, s. 57-68; tenże, Pragmatyczna piśmienność..., s. 72-78.

18 E. Gigilewicz, Zakres i znaczenie terminu ,sakralność” w piśmiennictwie polskim, [w:] Piśmiennictwo sakralne $w$ dziejach Polski do końca XVIII wieku na tle powszechnym, red. S. Bułajewski, J. Gancewski, A. Wałkówski, Józefów-Olsztyn 2012, s. 10, 12-13, 19, 24-25.

19 Archiwum Cystersów Mogilskich w Krakowie (Klasztor Ojców Cystersów). Rękopisy biblioteczne (dalej ACM, Rękop. bibl.), sygn. 613, 614, 615, 616, 617, 621, 623, 625, 626, 627, 629 i 630; BCzart., Dz. Rkp., sygn. 3734 III, 3789 III.

20 ACM, Rękop. bibl., sygn. 610, 612, 618, 619, 624 i 631; Katalog Archiwum Opactwa Cystersów w Mogile, oprac. K. Kaczmarczyk i G. Kowalski, Kraków 1919, s. 239 (nr 610), 240-241 (nr 612), 244-245 (nr 618-619), 250 (nr 624) i 258 (nr 631).

21 BCzart., Dz. Rkp., sygn. 3789 III; ACM, Rękop. bibl., sygn. 610; Katalog Archiwum..., s. 238-239 (nr 609 b-610).

22 ACM, Rękop. bibl., sygn. 612, 613, 614, 615, 616, 617, 618, 619, 621, 623; B.Czart., Dz. Rkp., sygn. 3734 III; Katalog Archiwum..., s. 240-245 (nr 610 a i 612-619), 246-250 (nr 621, 623).

23 ACM, Rękop. bibl., sygn. 624, 625, 626, 627, 629, 630, 631; Katalog Archiwum..., s. 250-258 (nr 624-627, 629-631).

24 E. Potkowski, Książka rękopiśmienna..., s. 124, przyp. 5. Zob. też K. Hoszowski, Obraz życia i zastug opatów mogilskich, Kraków 1867, s. 23-24; J. Dużyk, Nowa Huta, t. 2: Od średniowiecza do XIX wieku, Kraków 1957, s. 13; B. Miodońska, Małopolskie malarstwo książkowe 1320-1540, Warszawa 1993, s. 25; M. Starzyński, Katalog opatów mogilskich w średniowieczu, „Nasza Przeszłość” 2003, t. 100, s. 115. 
nikiem aktywizującym skryptorium w drugiej połowie XV w., co znalazło swoje odbicie w zachowanej podstawie źródłowej25.

Skupienie się na piśmiennictwie sakralnym wynika z jego wyraźnej przewagi $\mathrm{w}$ dorobku skryptoriów $\mathrm{i} \mathrm{w}$ spuściznach po bibliotekach klasztornych, zwłaszcza cysterskich ${ }^{26}$. Zamierzamy prześledzić, jakie odmiany tematyczne twórczości sakralnej dominują w kodeksach pochodzących ze średniowiecznej biblioteki klasztoru cystersów w Mogile. Chcemy każdą z tych odmian możliwie dokładnie omówić. W razie potrzeby będziemy je dzielić na mniejsze grupy tematyczne. Niezależnie jak głęboko będzie sięgać taka systematyka, zawsze zaprezentujemy poszczególne dzieła i ich autorów. Przyjrzymy się także kwestiom ilościowym. Szczególnie istotne może okazać się, czy taka sytuacja była typowa (i na ile) dla biblioteki i piśmiennictwa sakralnego cysterskiego skryptorium.

Granice chronologiczne naszych rozważań wyznacza częściowo podstawa źródłowa, częściowo - przemiany w kulturze piśmienniczej, jakie były udziałem klasztoru cystersów w Mogile. Skupiamy się na XV stuleciu, ponieważ z tego okresu pochodzą wszystkie zachowane kodeksy ${ }^{27}$. Jednocześnie schyłek tegoż stulecia i początek XVI w. to czasy zmian, które polegały na odchodzeniu od rękopisów, zanikaniu kopiowania ksiąg w skryptoriach i upowszechnianiu się druku ${ }^{28}$.

Struktura pracy została podyktowana omawianymi odmianami treściowymi piśmiennictwa sakralnego. Na początek przedstawiliśmy literaturę związaną z Biblią - Stary Testament, apokryfy, egzegezę. Dalej omówiliśmy teksty liturgiczne, modlitwy, kaznodziejstwo i duszpasterstwo. Następnie dokonaliśmy przeglądu dzieł ascetycznych i moralistycznych oraz mistycznych. Potem zajęliśmy się twórczością memoratywną i hagiografią (uwzględniając żywoty, ale też opisy męczeństwa i cudów), literaturą pasyjną oraz poezją i pieśniami na motywach religijnych. W zakresie teologii osobno wyróżniliśmy m.in. chrystologię, eschatologię.

Biblia. Stary Testament Mamy do czynienia jedynie z fragmentami: $\mathrm{Pa}$ rabole Salomonis ${ }^{29}$, Liber Ecclesiastes I-XII ${ }^{30}$, Cantica canticorum I-VIII ${ }^{31}$ oraz Liber Ecclesiasticus I-LI ${ }^{32}$.

\footnotetext{
25 Z. Domżał, A. Wałkówski, Imię róży inaczej..., s. 35, 37.

26 A. Wałkówski, Skryptoria cystersów filiacji portyjskiej..., s. 101-109, 402; tenże, Biblioteka klasztorna jako miejsce..., s. 118-128, 138.

27 Katalog Archiwum..., s. 238-259.

28 M. Starzyński, M. Zdanek, Mogiła w czasach Stanisława Samostrzelnika - szkic do dziejów klasztoru na przełomie XV i XVI wieku, „Cistercium Mater Nostra-Historia-Kultura” 2007, nr 1, s. 52.

29 ACM, Rękop. bibl., sygn. 615, fol. 1r-41r; tytuł na podstawie eksplicitu (fol. 41r) - [rubro:] Expliciunt parabole Salomonis; Katalog Archiwum..., s. 242 ( $\mathrm{nr}$ 615, poz. a) - według jego wydawców tytuł: Parabole [Proverbia] I-XXXI.

30 ACM, Rękop. bibl., sygn. 615, fol. 41r-65r; Katalog Archiwum..., s. 242 (nr 615, poz. b).

31 ACM, Rękop. bibl., sygn. 615, fol. 65v-83v; Katalog Archiwum..., s. 242 (nr 615, poz. c).

32 ACM, Rękop. bibl., sygn. 615, fol. 116v-204v (końcówka dzieła zaginęła z powodu ubytku stron); Katalog Archiwum..., s. 243 (nr 615, poz. e).
} 
Biblia. Apokryfy W jednym z czterech kodeksów z połowy XV w., zawierających Postyllę Mikołaja z Liry znajduje się krótki utwór ze Starego Testamentu - Modlitwa Manasessa, przypisywana królowi judzkiemu, a napisana po grecku przez Żyda w Aleksandrii w I w. p.n.e. (tego tekstu nie włączono do kanonu, nie jest też uznany za utwór deuterokanoniczny ${ }^{33}$.

Biblia. Egzegeza Na czoło wysuwa się dzieło franciszkańskiego uczonego Mikołaja z Liry Postilla litteralis super [totam] Bibliam, znane też jako Postilla litteralis, powstałe w latach 1322-1331. Ten systematyczny komentarz sensu wyrazowego Biblii stanowi najwybitniejsze dzieło egzegetyczne późnego średniowiecza. W swojej pracy Mikołaj wykorzystał m.in. teksty św. Hieronima i Talmudu. Trzeba dodać, że między 1350 a 1450 r. jego dzieło miało ok. 800 kopii i od XIV do XVI w. stanowiło podstawowy podręcznik egzegetyczny ${ }^{34}$. Zachowały się cztery jego części w czterech kodeksach z 1451 r.: Prima pars Lire quinque libros Moysi ${ }^{35}$, Secunda pars Lire super Josue, Iudicum, Regum, Paralippomenon et Danielem ${ }^{36}$, Quarta pars Lire super libros Sapiencie ${ }^{37}$ oraz Quinta pars Lire super Actus apostolorum, Canonicas epistolas ac Apocalipsim ${ }^{38}$. Tylko jeden z tych kodeksów posiada nadaną datację w kolofonie Jana Jordana z Dachau, prezbitera diecezji we Fryzyndze: Finita est hec postilla fratris Nicolai de lyra ordinis fratrum minorum Sacre pagine professoris Anno domini Millesimo quadringentesimo quinquagesimo primo in vigilia Sancti Thome apostoli [rubro:] Frisinge per manus Johannis Jordan de Dachaw frisingensis dijocesis presbiteri ${ }^{39}$. Rękopis został więc spisany w 1451 r., a kopiowanie ostatniej części zakończono zapewne 20 grudnia.

Pozostałe trzy kodeksy nie mają tego rodzaju datacji, ale ich pismo pochodzi z połowy XV stulecia ${ }^{40}$. Stanowią one części tworzące z piątą jedną całość. Istnieje paleograficzne podobieństwo ich pisma do duktu kodeksu, który ją zawiera i posiada nadaną datację w kolofonie na $1451 \mathrm{r}$. Można więc przyjąć ten rok jako prawdopodobny czas sporządzenia ksiąg z częściami pierwszą, drugą i czwartą ${ }^{41}$.

33 ACM, Rękop. bibl., sygn. 614, fol. 307r; Katalog Archiwum..., s. 242 (nr 614, poz. f); M.D. Coogan, Manasses, [w:] Stownik wiedzy biblijnej, red. B.M. Metzger, M.D. Coogan, Warszawa 1996, s. 497; W.R.F. Browing, Stownik Biblii, Warszawa 2005, s. 304.

${ }_{34}$ S. Szymik, Mikotaj z Liry, [w:] Encyklopedia Katolicka, t. 12, red. A. Bednarek i in., Lublin 2008, kol. 1005-1006.

35 ACM, Rękop. bibl., sygn. 613; Katalog Archiwum..., s. 241 (nr 613).

36 ACM, Rękop. bibl., sygn. 614; Katalog Archiwum..., s. 241-242 (nr 614).

37 ACM, Rękop. bibl., sygn. 615; Katalog Archiwum..., s. 242-243 (nr 615).

38 ACM, Rękop. bibl., sygn. 616; Katalog Archiwum..., s. 243-244 (nr 616).

39 ACM, Rękop. bibl., sygn. 616, fol. 184r; patrz fot. 1.

40 Por. ACM, Rękop. bibl., sygn. 613-615, por. Katalog Archiwum..., s. 241-243 (nr 613-615).

${ }^{41}$ Por. ACM, Rękop. bibl., sygn. 616 z sygn. 613-615; Katalog Archiwum..., s. 241-244 (nr 613-616). 
Fot. $1^{42}$

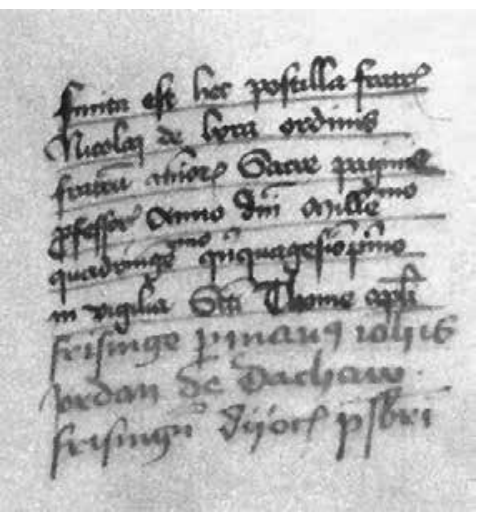

Kolofon Jana Jordana z Dachau prepozyta diecezji we Freising. ACM,

Rękop. bibl., sygn. 616, fol. $184^{r}$
Za tym przemawia sporządzenie zakończenia w języku niemieckim (,,Sweyg leyd und lache gedult verriecht vil sache"43) w kopii komentarza Mikołaja z Liry do Księgi Sędziów, w kodeksie zawierającym drugą część Postylli Mikołaja z Liry ${ }^{44}$. Język wyżej zacytowanego zdania wiąże go z Niemcami, miejscem pracy wspomnianego wyżej w kolofonie kopisty Jana Jordana z Dachau.

Fot. 2

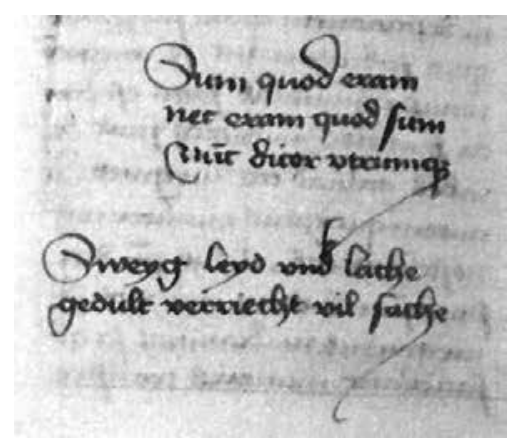

Niemiecki tekst kończący komentarz Mikołaja z Liry (dwa ostatnie wiersze). ACM, Rękop. bibl., sygn. 614 , fol. $66^{\mathrm{v}}$ gi z argumentacji z rozdziałów Postylli Mikołaja z Liry, której część pierwszą stanowi kodeks ACM, Rękop. bibl., sygn. 613 (pozostałe części bez drugiej - sygn. 614, 615, 616). Wyciągi te mają kształt zbliżony do tabelarycznego (pisarz podzielił strony liniami pionowymi i poziomymi na kolumny oraz wiersze tak jak w tabeli, a w powstałe W ten sposób rubryki wpisywał tekst) ${ }^{47}$. Następny komentarz Mikołaja to Postilla super Genesis. Prologus secundus ${ }^{48}$, a dalej w kolejności: Prologus primus super Genesis de commendatione sacre scripture in generali ${ }^{49}$,

\footnotetext{
42 Autorzy dziękują dr. Zbigniewowi Gruszce z Katedry Informatologii i Bibliologii Uniwersytetu Łódzkiego za wykonanie fotografii wykorzystanych w artykule.

43 ACM, Rękop. bibl., sygn. 614, fol. 66v; patrz fot. 2.

44 Tamże; Katalog Archiwum..., s. 241 (nr 614, poz. b).

45 ACM, Rękop. bibl., sygn. 613, fol. 2-13v.

46 Katalog Archiwum..., s. 241 (nr 613, poz. a).

47 ACM, Rękop. bibl., sygn. 613, fol. 2-13v.

48 Tamże, fol.14r-90v (w rękopisie: Super Genesis); Katalog Archiwum..., s. 241 (nr 613, poz. b).

49 ACM, Rękop. bibl., sygn. 613, fol. 90v-97r; Katalog Archiwum..., s. 241 (nr 613, poz. c).
} 
Postilla super Exodum ${ }^{50}$, Postilla super Leviticum ${ }^{51}$, Postilla super Numeros $^{52}$ oraz kończąca kodeks Postilla super Deuteronomium ${ }^{53}$. Następny manuskrypt zawiera drugą cześć Postylli Mikołaja z Liry: Secunda pars Lire super Josue, Iudicum, Regum, Paralippomenon et Danielem ${ }^{54}$. Otwiera go Postilla super librum Josue ${ }^{55}$. W dalszej kolejności następują: Liber Iudicum I-XXI ${ }^{56}$, Postilla fratris Nicolai de Lira super Ruth ${ }^{57}$, Postilla super [IV] libros regum ${ }^{58}$, Postilla super duos libros Paralippomenon $^{59}$ oraz kończąca ten kodeks Postilla super Danielem ${ }^{60}$. Rękopis trzeci zawiera czwartą część dzieła Mikołaja: Postilla magistri Nicolai de Lira super librum sapiencie ${ }^{61}$. W czwartym kodeksie znajduje się Quinta pars Lire super Actus apostolorum, Canonicas, epistolas ac Apocalipsim ${ }^{62}$, grupująca komentarze Mikołaja dotyczące: Actus apostolorum I-XXVIII ${ }^{63}$, Super epistolas canonicas $^{64}$ (o listach apostołów: Jakuba I-V z prologiem $^{65}$, pierwszym Piotra I-V ${ }^{66}$, drugim Piotra I-III ${ }^{67}$, pierwszym Jana I-V ${ }^{68}$,

50 Tamże, s. 241 (nr 613, poz. d); ACM, Rękop. bibl., sygn. 613, fol. 98r-158v - tytuł oryginalny: Exodus capitulum primum. [Rubro:] Capitulum primum - napis na górnym marginesie fol. 98r. Między fol. 106v a 107r kartka mniejszego formatu zapisana obustronnie z uzupełnieniem inną ręką z połowy, ewentualnie $\mathrm{z}$ drugiej połowy XV w.

51 ACM, Rękop. bibl., sygn. 613, fol.160r-202v (Leuiticus - tytuł w rękopisie, rubro nad początkiem tekstu); Katalog Archiwum..., s. 241 (nr 613, poz. e).

52 ACM, Rękop. bibl., sygn. 613, fol.160r-255v (tytuł rubro nad początkiem tekstu Postylli: Numeri); Katalog Archiwum..., s. 241 (nr 613, poz. f).

53 ACM, Rękop. bibl., sygn. 613, fol. 256r-308v (tytuł rubro nad początkiem tekstu na górnym marginesie: Deuteronomium); Katalog Archiwum..., s. 241 (nr 613, poz. g).

54 Tamże, s. 241-242 (nr 614).

55 ACM, Rękop. bibl., sygn. 614, fol.1r-32v. Tytuł na podstawie eksplicitu - fol. 32v: Explicit Postilla super librum Josue edita a fratre Nicolao de Lyra de ordine fratrum minorum sacre theologie proffessore; Katalog Archiwum..., s. 241 (nr 614, poz. a) podaje inny tytuł: Josue I-XXIV.

56 ACM, Rękop. bibl., sygn. 614, fol. 33r-66v; Katalog Archiwum..., s. 241 (nr 614, poz. b).

57 ACM, Rękop. bibl., sygn. 614, fol. 67r-72r, tytuł podany za eksplicitem rękopisu: [rubro:] finis. Explicit postilla fratris Nicolai de Lira super Ruth (fol. 72r); Katalog Archiwum..., s. 242 (nr 614, poz. c) podaje tylko: Ruth I-III.

58 ACM, Rękop. bibl., sygn. 614, fol. 72r-238v; Katalog Archiwum..., s. 242 (nr 614, poz. d).

59 ACM, Rękop. bibl., sygn. 614, fol. 241r-306v (w rękopisie tytuł krótko: Super Paralippomenon); Katalog Archiwum..., s. 242 (nr 614, poz. e).

60 ACM, Rękop. bibl., sygn. 614, fol. 312r-395v; Katalog Archiwum..., s. 242 (nr 614, poz. g).

61 ACM, Rękop. bibl., sygn. 615, fol. 83v-116r - tytuł na podstawie eksplicitu (fol. 116r, rubro:) Explicit Postilla magistri Nicolai de Lira super librum sapiencie; Katalog Archiwum..., s. 242-243 (nr 615, poz. d) - wg wydawców: Postilla magistri Nicolai de Lira super librum sapiencie.

62 ACM, Rękop. bibl., sygn. 616; Katalog Archiwum..., s. 243-244 (nr 616).

63 ACM, Rękop. bibl., sygn. 616, fol.5r-71v; Katalog Archiwum..., s. 243 (nr 616, poz. a).

64 ACM, Rękop. bibl., sygn. 616, fol.71v-122v; Katalog Archiwum..., s. 243-244 (nr 616, poz. b).

65 ACM, Rękop. bibl., sygn. 616, fol. 71v-84v; Katalog Archiwum..., s. 243 (nr 616, poz. b/1).

66 ACM, Rękop. bibl., sygn. 616, fol. 84v-94v; Katalog Archiwum..., s. 243 (nr 616, poz. b/2).

67 ACM, Rękop. bibl., sygn. 616, fol. 95r-103r; Katalog Archiwum..., s. 243 (nr 616, poz. b/3).

68 ACM, Rękop. bibl., sygn. 616, fol. 103r-116v; Katalog Archiwum..., s. 243 (nr 616, poz. b/4). 
drugim $^{69}$ oraz liście trzecim ${ }^{70}$, a na końcu o liście Judy ${ }^{71}$ ) oraz Apocalipsis $I-X X I I^{72}$.

Ze średniowiecznych zbiorów bibliotecznych klasztoru cystersów w Mogile zachowało się dzieło krytyczne wobec Postylli Mikołaja z Liry. Autorem tekstu był Paweł: od 1415 r. arcybiskup Burgos, a od 1416 - kapelan króla Kastylii Henryka III. W swoim dziele, w oparciu o lepszą znajomość języka hebrajskiego (był z pochodzenia Żydem i wcześniej nazywał się Salomon ha Levi), krytycznie odniósł się do alegorycznej egzegezy Biblii. Zarzucił Mikołajowi niedostateczne wykorzystanie pism Ojców Kościoła, Tomasza z Akwinu i uczonych żydowskich. Te krytyczne poglądy wyraził w dziele Additiones ad Postillam Nicolai de Lira (Nicolai Lyrani) ${ }^{73}$. Kopia tej rozprawy znajduje się w kodeksie datowanym na 1451 r., co potwierdza pismo z połowy XV stulecia ${ }^{74}$. Twórcy Katalogu Archiwum ... - K. Kaczmarczyk i G. Kowalski - przyjęli jako datację rok 1451, ale nie podali uzasadnienia. Musieli kierować się treścią księgi, nawiązującą do czterech części Postylli Mikołaja z Liry, z których jedna zawiera wspomniany kolofon Jana Jordana $z$ Dachau datowany na ten rok $^{75}$. Na początku kodeksu wymieniono nie tylko autora (Pawła) i tytuł dzieła, ale także czas zakończenia pracy nad nim: Incipiunt Additiones ad Postillam Magistri Nicolai de lira super biblia edite a reverendo patre domino Paulo de Sancta Maria Magistro in Theologia Episcopo Burgensi ${ }^{76}$ nato iudeo archicancellario Serenissimi domini Johanno Regis Castelle et legionis ${ }^{77}$, quas Venerabili viro Alfonsio legum doctori decano Compostallano filio suo ex legitimo matrimonio genito dixerit Premittens ei prologum sub forma sequenti, finivit autem eas Anno domini $M C C C C X X I X^{78}$.

${ }^{69}$ ACM, Rękop. bibl., sygn. 616, fol. 116v-118r; Katalog Archiwum..., s. 243 (nr 616, poz. b/5).

70 ACM, Rękop. bibl., sygn. 616, fol. 118r-119v; Katalog Archiwum..., s. 243 (nr 616, poz. b/6).

71 ACM, Rękop. bibl., sygn. 616, fol. 119v-122v; Katalog Archiwum..., s. 244 (nr 616, poz. b/7).

72 ACM, Rękop. bibl., sygn. 616, fol. 123r-184r; Katalog Archiwum..., s. 244 (nr 616, poz. c).

73 S. Szymik, Mikołaj z Liry..., kol. 1005-1006; P. Królikowski, Pawet z Burgos, [w:] Encyklopedia Katolicka, t. 15, red. E. Gigilewicz, Lublin 2011, s. 129; I. Singer, M. Kayserling, Paul de Burgos or Paul de Santa Maria (Jewish nam, Solomon ha-Levi) [online], <www. jewishencyclopedia.com/articles/11950-paul-de-burgos> (24 XI 2016).

74 ACM, Rękop. bibl., sygn. 617. O datacji pisma świadczy jego podobieństwo do duktu Jana Jordana z Dachau (sygn. 616) i pewne analogie do ,pisma płomienistego” - por. A. Gieysztor, Zarys dziejów pisma łacińskiego, Warszawa 2009, s. 136.

75 Katalog Archiwum..., s. 244 (nr 617); ACM, Rękop. bibl., sygn. 616, fol. 154r.

76 W rzeczywistości był od 1415 r. arcybiskupem Burgos - zob. P. Królikowski, Paweł z Burgos..., s. 129.

77 Jan II, król Kastylii i Leonu w latach 1406-1454 - zob. J.E. Morby, Dynastie świata. Przewodnik chronologiczny i genealogiczny, Kraków 1995, s. 184.

78 ACM, Rękop. bibl., sygn. 617, fol. 1r; por. fot. 3 - Subskrypcja Addtitiones Pawła arcybiskupa Burgos. 
Fot. 3

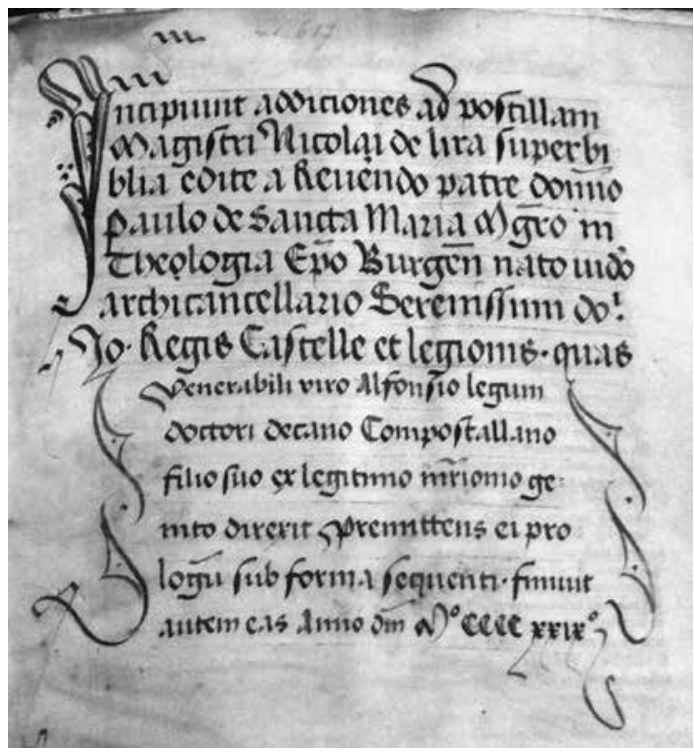

Subskrypcja Additiones Pawła arcybiskupa Burgos. ACM, Rękop. bibl., sygn. 617 , fol. $1^{\mathrm{r}}$
Ponieważ nota ta występuje na początku, nie jest to kolofon w ścisłym tego słowa znaczeniu, ale forma subskrypcji ${ }^{79}$. Obok przestawiamy jej fotokopię.

Additiones... zajmują całość kodeksu liczącego ponad $200 \mathrm{kart}^{80}$.

Następne dwa dzieła egzegetyczne znajdują się w kodeksie datowanym przez K. KaczmarczykaiG. Kowalskiego na lata $1464-1477^{81}$, którzy tej datacji nie uzasadnili. Możemy się domyślać, że chodziło im o to, iż w jednym z rękopisów jest kolofon Jana z Gniezna datowany na rok 1464: Explicit liber Sentenciarum Scriptus Cracovie per me Johannem de Gnezna

filium olim petri dimicatoris Anno domini millesimo quadrincesimo sexagesimo quarto Amen ${ }^{82}$. Tymczasem rękę kopisty spotykamy w całym omawianym kodeksie ${ }^{83}$. Zapewne dlatego K. Kaczmarczyk i G. Kowalski przyjęli rok 1464 jako początkową datę spisywania woluminu. Natomiast rok 1477 jako data końcowa może wynikać z tego, że mamy do czynienia z inną księgą, której pierwsze 62 karty spisał Jan z Gniezna ${ }^{84}$. Według noty i kolofonu nastąpiło to właśnie w 1477 r. ${ }^{85}$ Ręki Jana nie spotykamy w dalszych kodeksach i prawdopodobnie dlatego K. Kaczmarczyk i G. Kowalski przyjęli rok 1477 jako końcową granicę. Takiej sytuacji nie można wykluczyć, ale jest ona dość niepewna. W tym układzie przyjmujemy rok 1477 jako cezurę końcową ze znakiem zapytania. Pierwsze dzieło spisane przez Jana z Gniezna, to Corpus evangelicum, zawierające objaśnienia i teksty czterech Ewangeliii ${ }^{86}$. O pracy Jana świadczy kolofon rubro:

\footnotetext{
79 Por. Jak czytać rękopis średniowieczny, red. P. Géhin, Warszawa 2008, s. 136.

80 ACM, Rękop. bibl., sygn. 617, fol. 1r-203r; Katalog Archiwum..., s. 244 (nr 617).

81 Tamże, s. 252-253 (nr 627).

82 ACM, Rękop. bibl., sygn. 626, fol. 96v.

83 ACM, Rękop. bibl., sygn. 627; Katalog Archiwum..., s. 252-253 (nr 627).

84 ACM, Rękop. bibl., sygn. 628; Katalog Archiwum..., s. 253 (nr 628).

85 ACM, Rękop. bibl., sygn. 628, fol. 63r i 249r; Katalog Archiwum..., s. 253 (nr 628).

86 ACM, Rękop. bibl., sygn. 627, fol. 3r-332r; Katalog Archiwum..., s. 252 (nr 627, poz. a).
} 
Explicit corpus euangelicum per Joh [przekreślone] me Johannem de Gnezna filium olim petri dimicatoris scriptum Cracouie ${ }^{87}$. Niżej znajduje się fotokopia tego kolofonu.

Fot. 4

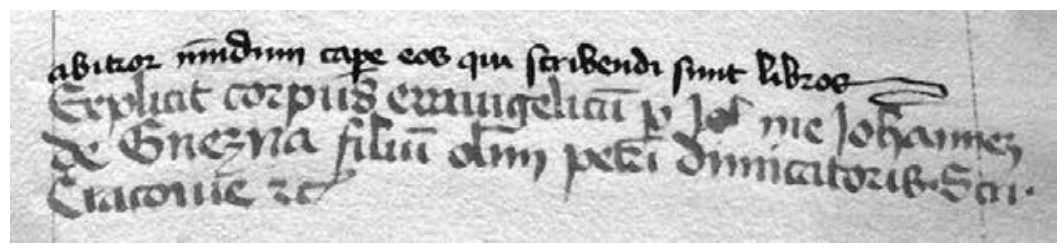

Pierwszy kolofon Jana z Gniezna. ACM, Rękop. bibl., sygn. 627 , fol. $332^{\mathrm{r}}$

Drugie dzieło, które wyszło spod ręki Jana z Gniezna, to Epistole canonice, stanowiące objaśnienia i teksty listów świętych: Jakuba, Piotra oraz $\mathrm{Judy}^{88}$, zaś o pracy kopisty wiemy z mocno wybrakowanego (z powodu ubytków karty) kolofonu: [Epistole can]onice per me Johannem de Gnezna filium olim [Petri dimicat]oris Amen ${ }^{89}$, który jest widoczny na załączonej niżej fotografii.

Fot. 5

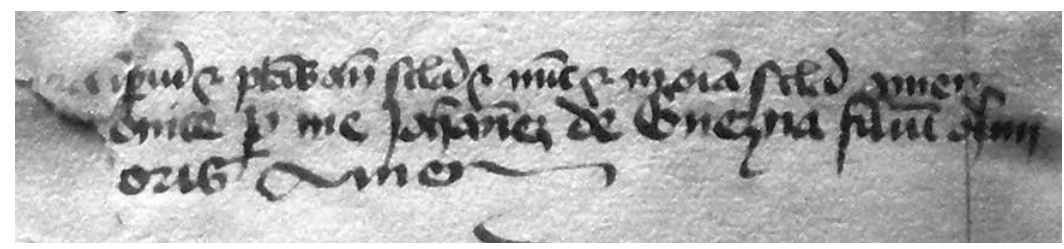

Drugi kolofon Jana z Gniezna. ACM, Rękop. bibl., sygn. 627, fol. 353v , kolofon zaczyna się od drugiego wiersza

Liturgia. Kolekty i kapitula Zachował się kodeks datowany na rok 1406, który znany jest pod dwoma tytułami: Missale parvum. Orationes et responsoria $^{90}$ oraz Collectaneum cisterciense ${ }^{91}$. Kodeks ten powstał najprawdopodobniej około lat 1406-1407, ponieważ od 1406 r. zaczynają się litery niedziel i indykcje. Ponadto wykonano ręką z XV w. notę: Nota:

\footnotetext{
87 ACM, Rękop. bibl., sygn. 627, fol. 332r.

88 Tamże, fol. 333r-353v; Katalog Archiwum..., s. 252 (nr 627, poz. b).

89 ACM, Rękop. bibl., sygn. 627, fol. 353v.

90 BCzart., Dz. Rkp., sygn. 3789 III; Katalog Archiwum..., s. 239 (nr 609 b).

91 BCzart., Dz. Rkp., sygn. 3789 III, przed pag. 1 dołączona współczesna kartka, a na niej długopisem uwaga, że tytuł ma brzmieć: Collectaneum cisterciense. Na jej odwrocie kartki notatka ołówkiem ks. [Juliana] Wojtkowskiego z 1951 r., że kodeks zawiera: „kolekty i kapitula, jest więc konceptem brewiarza, a nie mszału".
} 
Eclipsis solis fuit in crastino sancti Viti martyris feria IIII anno Domini MCCCCVI [w Katalogu archiwum błędnie MCCCVI] ${ }^{92}$. Inna nota dotycząca datacji brzmi: Nota, quod IIII kalendas Aprilis, II et III feria Pasche occiderunt Christiani Iudeos, propter quendam scolarem christianum, quem ipsi occiderunt inter festum ipsorum anno Domini MCCCCVII ${ }^{93}$. Pismo może potwierdzać tę datację, ponieważ w głównym trzonie jest to kaligraficzna formata (littera textualis formata) z przełomu XIV i XV w. ${ }^{94} \mathrm{~W}$ omawianym kodeksie znajdziemy: Collecte de sanctis per totum annum, qui non habent propiras in collectario collectas per notantur per litteras alphabeti sequentes de uno martyre pontifice ${ }^{95}$. Tytuł ten wynika $\mathrm{z}$ incipitu $\mathrm{w}$ rękopisie $^{96}$, a według katalogu powinien brzmieć: Collectaneum Cisterciense - liber ceremonialis ordinis, excerptum breviarii ${ }^{97}$.

Liturgia. Kalendarz Drugą pozycję w omawianej księdze stanowi $\mathrm{Ca}$ lendarium cum chronologia ${ }^{98}$ - „Kalendarz z wykazem świętych wg miesięcy oraz początkami czytań i wersetów oraz tablice epaktów, indykcji oraz Paschy na lata 1406-1669"99.

Liturgia. Brewiarz Breviarium Cisterciense zajmuje cały kodeks z roku $1412^{100}$. Data ta znajduje się w kolofonie, który oprócz pisarza i właściciela kodeksu podaje też osobę czasowo go użytkującą: Iste liber est sancte Marie Virginis sanctique Wenzeslai martyris et fratris Gyskonis monachi in Claratumba alias Mogila, professi, qui scriptus et finitus est adiutorio dei per fratrem Arnoldum ibidem professum in ordine Cysterciensi in crastino beati Thome apostoli Sub anno incarnacionis domini Millessimo $\mathrm{CCCC}^{\circ} \mathrm{XII}^{\circ}$. Orate pro eis ${ }^{101}$.

92 Tamże, pag. 6; Katalog Archiwum..., s. 238 (nr 609 b).

93 BCzart., Dz. Rkp., sygn. 3789, pag. 8.

94 Por. W. Semkowicz, Paleografia łacińska, Kraków 2002, s. 315-324 i A. Gieysztor, dz. cyt., s. 127-130 z BCzart., Dz. Rkp., sygn. 3789 III. Wskazują na to: ostrzejsze łamanie liter, ich większe stłoczenie i cięższa budowa $\mathrm{z}$ zachowaniem jednak staranności oraz czytelności, stosowanie $a$,pozawłoskiego", okrągłego $r$ występującego nie zawsze po wypukłych krawędziach liter czy okrągłego $s$ obustronnie zamkniętego, jak również $t$ z poprzeczką bardzo rozbudowaną z prawej strony, a słabo $-\mathrm{z}$ lewej.

95 Tamże, pag. 1-6 i 29-153. Tekst ten został przedzielony kalendarzem na dwie części; pierwsza - pag. 1-6, druga - pag. 29-153.

96 Tamże, pag. 1: [Rubro] Incipiunt collecte de sanctis per totum annum, qui non habent propiras in collectario collectas per notantur per litteras alphabeti sequentes de uno martyre pontifice.

97 Tymczasowy katalog rękopisów średniowiecznych Biblioteki Książąt Czartoryskich, sygn. 2317-3982, Kraków 1984-1995 (niepublikowany maszynopis, BCzart.), sygn. 3789 III.

98 BCzart., Dz. Rkp., sygn. 3789 III, pag. 7-28; tytuł za: Katalog Archiwum..., s. 238 (nr 609 b).

99 Tytuł za Tymczasowy katalog..., sygn. 3789 III.

100 ACM, Rękop. bibl., sygn. 610; Katalog Archiwum..., s. 239-240 (nr 610).

101 ACM, Rękop. bibl., sygn. 610, fol. 559v; Katalog Archiwum..., s. 239 (nr 610). 
Można więc wnioskować, że Arnold spisał ten kodeks, przynajmniej częściowo (do fol. 559v), w roku $1412^{102}$. Omawiany brewiarz zawiera: Calendarium (bez czerwca oraz lipca) ${ }^{103}$, Proprium et Lectiones de tempore a prima dominica Adventus usque ad dominicam XXV post Pentecostes ${ }^{104}$, Proprium et Lectiones de sanctis et communes ${ }^{105}$, Sequitur ympnus dominicis et privatis diebus per totum annum praeter festa, quae habent proprios ympnus ${ }^{106}$, Sequuntur cantica dominis diebus ${ }^{107}$, Psalterium per hebdomadam dispositum $^{108}$, Sequitur pro defunctis ${ }^{109}$, Sequitur dominicis diebus benedictio salis ${ }^{110}$, Suspirium sancti Augustini ad sanctam mariam et ad omnes sanctos et ad sanctam Trinitatem ${ }^{111}$, a na końcu Orationes et benedictiones ${ }^{112}$.

Liturgia. Antyfonarz Zachował się we fragmentach pochodzący z połowy XV w. antyfonarz Antiphonarium Cisterciense a dominica tertia Quadragesimae usque ad Nativitaem B.V.M. ${ }^{113}$

Liturgia. Hymny W tym przypadku mamy do czynienia ze zbiorem: [Rubro:] Ympni de tempore ad tertiam [Dominicam?] per adventum domini, preter festa sanctorum, czyli z „Hymnami od trzeciej niedzieli Adwentu oprócz święta Wszystkich Świętych" w kodeksie z połowy XV w. ${ }^{114}$

Liturgia Officium divinum - kodeks zawiera Formula legendi secundum consuetudinem ordinis cisterciensis, composita in monasterio Porta (Zasady czytania Ewangelii u cystersów ${ }^{115}$. Tekst sporządzony dwiema rękami, z któ-

102 S. Tomkowicz, Powiat krakowski, „Teka Grona Konserwatorów Galicji Zachodniej” 1906, t. 2, s. 190; E. Chwalewik, Zbiory polskie. Archiwa, biblioteki, gabinety, galerie, muzea i inne zbiory pamiatek przeszłości w ojczyźnie i na obczyźnie w porządku alfabetycznym wedlug miejscowości ułożone, t. 1: A-M, Warszawa-Kraków 1926, s. 464; Zbiory rękopisów w bibliotekach i muzeach w Polsce, oprac. D. Kamolowa, przy współudziale K. Muszyńskiej (zbiory kościelne), Warszawa 1988, s. 146; B. Miodońska, dz. cyt., s. 88, przyp. 120; Z. Domżał, A. Wałkówski, Imię róży inaczej..., s. 131-132.

${ }^{103}$ ACM, Rękop. bibl., sygn. 610, fol. 1v-6r; Katalog Archiwum..., s. 239 (nr 610, poz. a).

${ }_{104}$ ACM, Rękop. bibl., sygn. 610, fol. 8r-308v; Katalog Archiwum..., s. 239 (nr 610, poz. b).

${ }_{105}$ ACM, Rękop. bibl., sygn. 610, fol. 308v-513v; Katalog Archiwum..., s. 239 (nr 610, poz. c).

106 ACM, Rękop. bibl., sygn. 610, fol. 514r-526r; Katalog Archiwum..., s. 239 (nr 610, poz. d).

107 ACM, Rękop. bibl., sygn. 610, fol. 526r-529r; Katalog Archiwum..., s. 239 (nr 610, poz. e).

108 ACM, Rękop. bibl., sygn. 610, fol. 529v-555v; Katalog Archiwum..., s. 239 (nr 610, poz. f).

109 ACM, Rękop. bibl., sygn. 610, fol. 555v; Katalog Archiwum..., s. 239 (nr 610, poz. g).

110 ACM, Rękop. bibl., sygn. 610, fol. 558v-559v; Katalog Archiwum..., s. 239 (nr 610, poz. h).

111 ACM, Rękop. bibl., sygn. 610, fol. 560r-562r; Katalog Archiwum..., s. 239 (nr 610, poz. i).

112 ACM, Rękop. bibl., sygn. 610, fol. 562r-573r; Katalog Archiwum..., s. 239 (nr 610, poz. i).

113 ACM, Rękop. bibl., sygn. 619, fol. 53r- 123r i 175r-211r; Katalog Archiwum..., s. 245 (nr 619).

114 BCzart., Dz. Rkp., sygn. 3734 III, pag. 114-120; Tymczasowy katalog..., sygn. 3789 III. Datacja kodeksu wynika z kolofonu opata P. Hirszberga, który wymienia rok 1447 (BCzart., Dz. Rkp., sygn. 3734 III, pag. 119). Ręka kontynuująca pracę Piotra (pag. 119-120) wykazuje się znacznym podobieństwem i można ją datować na połowę XV stulecia.

${ }_{115}$ BCzart., Dz. Rkp., sygn. 3734 III, pag. 121-143 Tytuł za incipitem (pag. 121) - [Rubro:] Incipit formula legendi secundum consuetudinem ordinis cisterciensis, composita in monasterio porta que est aui nostri monasterii; Tymczasowy katalog..., sygn. 3789 III; Katalog Archiwum..., s. 240 (nr 610 a, poz. b). 
rych pierwsza jest podobna do duktu Piotra Hirszberga z 1447 r., a następną można datować na drugą połowę XV w. ${ }^{116}$

Modlitwa Oratio ad Christum zachowała się w kodeksie pochodzącym z lat 1479-1480 ${ }^{117}$. Datacja księgi została oparta o dwa kolofony - z 1479 i 1480 r. ${ }^{118}$

Kaznodziejstwo Na czoło wysuwa się dzieło P. Hirszberga Epistolae dominicales per totum annum (zbiór 119 krótkich kazań) ${ }^{119}$. Według kolofonu Hirszberg ukończył swoją pracę 28 marca 1447 r.: Expliciunt epistole de tempore per manus fratris Petri hirsberg feria sexta ante palmarum Anno domini Millesimo quadringentesimo quadragesimo septimo ${ }^{120}$. Początek dzieła musiał zostać wcześniej zniszczony i zrekonstruowano go później ręką z połowy XVI w., która spisała poprzedzającą go pieśń zaopatrzoną w nutację rombową ${ }^{121}$. Następna pozycja zachowała się w kodeksie datowanym na 1452 r. ${ }^{122}$ Sa to: Sermones super quatuor lectiones officii defunctorum ${ }^{123}$. $\mathrm{Z}$ drugiej połowy XV w. pochodzi kodeks będący zbiorem 37 kazań: Sermones de sanctis, vitae cum miraculis eorundem sanctorum et virginis Mariae, sanctis patrum et diversorum scriptorum ${ }^{124}$. Datacja kodeksu może zostać uściślona i określona ramowo, a wynika ona $\mathrm{z}$ trzech informacji zawartych w rękopisie. Pierwsza z nich odnosi się do 1464 r. [rubro:] Sequitur sermo de presentacione in templum sancte marie virginis in quo continentur due bulle de indulgenciis huius facie festiuitatis. Została ona ustalona przez K. Kaczmarczyka i G. Kowalskiego na podstawie daty bulli papieża Pawła II o odpuście z okazji wyżej wymienionego święta. Jednak ci sami wydawcy Katalogu... wskazują na zarządzenie tego święta przez arcybiskupa Moguncji w 1468 r. Obie informacje są w Kazaniu o święcie Ofiarowania Najświęt-

116 BCzart., Dz. Rkp., sygn. 3734 III, pag. 121-142 (pierwsza ręka z połowy XV wieku), pag. 143 (ręka następna z drugiej połowy XV wieku). Por. także Katalog Archiwum..., s. 240 (nr 610 a) i Tymczasowy katalog..., sygn. 3789 III.

117 ACM, Rękop. bibl., sygn. 631, fol 359r-361r, 364r-366r; Katalog Archiwum..., s. 258 (nr 631, poz. m).

118 ACM, Rękop. bibl., sygn. 631, fol. 73v, 265r; Katalog Archiwum..., s. 258 (nr 631).

119 BCzart., Dz. Rkp., sygn. 3734 III, pag. 3-114, Katalog Archiwum..., s. 240 (nr 610 a, poz. a); Tymczasowy katalog..., sygn. 3734 III.

${ }^{120}$ BCzart., Dz. Rkp., sygn. 3734 III, pag. 119. Umieszczono go nie tylko po części zawierającej Epistolae Dominicales per Totum Annum, lecz także po załączonych do nich hymnach. Wygląda na to, że kolofon odnosi się więc także do tych hymnów, chociaż o nich nie wspomina. Być może P. Hirszberg potraktował kazania i hymny jako całość. Por. Tymczasowy katalog..., sygn. 3734 III.

121 BCzart., Dz. Rkp., sygn. 3734 III, pag. 3-4 (pieśń z nutacją rombową - pag. 1-2); por. Tymczasowy katalog..., sygn. 3734 III.

122 ACM, Rękop. bibl., sygn. 618 - data MCCCCLII - fol. 93r; Katalog Archiwum..., s. 244-245 (nr 618, poz. b).

123 ACM, Rękop. bibl., sygn. 618, fol. 97r-109r; Katalog Archiwum..., s. 244-245 (nr 618, poz. b).

124 ACM, Rękop. bibl., sygn. 625, pag. 3-772; Katalog Archiwum..., s. 251 (nr 625, poz. a/1-37). 
szej Marii Panny (21 listopada) ${ }^{125}$. Jest jeszcze późniejsza data - wzmianka o pielgrzymce do relikwii błogosławionej Katarzyny, która miała miejsce w 1471 r. ${ }^{126}$ Tymczasem daty 1464 i 1468 mówią o wydarzeniach z przeszłości poprzedzających spisanie kodeksu. Nie ma więc podstaw, aby przyjmować je jako chronologiczne ramy początkowe jego powstania, skoro jest także mowa o wydarzeniu z roku 1471, również sprzed spisania lub najpóźniej w trakcie tworzenia datowanej księgi. Dlatego przyjmujemy ją jako post quem. Natomiast data ante quem to rok 1490, który znajduje się w dodatku do kolofonu Mikołaja z Krakowa i dookreśla czas powstania ${ }^{127}$. Porównajmy załączoną niżej fotografię.

Fot. 6

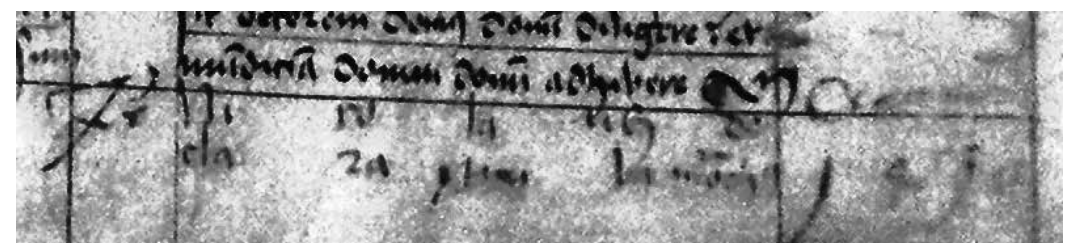

Kolofon Mikołaja z Krakowa z uzupełnieniem w postaci roku 1490. ACM, Rękop. bibl., sygn. 625, pag. 851

W kodeksie powstałym po 1471 r. zachowały się: zbiory kazań, które K. Kaczmarczyk i G. Kowalski określili jako Varii sermones (sześć kazań) ${ }^{128}$, Diversi sermones (pięć kazań) ${ }^{129}$ oraz jedno Sermo de bona voluntate (libero arbitro $)^{130}$. Datacja kodeksu jest oparta na podstawie najpóźniej datowanego tekstu w tej księdze, tj. listu Kazimierza Jagiellończyka do Macieja Hunyadyego [Korwina] dotyczącego pretensji do korony Węgier. List ten nosi datę 6 września $1471 \mathrm{r}^{131}$ Badania paleograficzne potwierdzają ten czas ${ }^{132}$. Czwar-

125 Tamże, s. 252 (nr 625, poz. a/35); ACM, Rękop. bibl., sygn. 625, pag. 745-753; Chronologia polska, red. B. Włodarski, Warszawa 2007, s. 252.

126 ACM, Rękop. bibl., sygn. 625, pag. 709; Katalog Archiwum..., s. 251 (nr 625, poz. a/32).

127 Kolofon brzmi [rubro:] Nicolaus de claratumba monachus; dodatek [nigro:] Frater Cracoviensis 1490 - ACM, Rękop. bibl., sygn. 625, pag. 851; Katalog Archiwum..., s. 252 (nr 625); patrz. fot. 6.

128 ACM, Rękop. bibl., sygn. 630, fol. 107r-112v, 135r-141r, 143r-148r, 152r-162v; Katalog Archiwum..., s. 256-257 (nr 630, poz. f/1, 2, 4, 6, 8, 9).

${ }_{129}$ ACM, Rękop. bibl., sygn. 630, fol. 199r-206v; Katalog Archiwum..., s. 257-258 (nr 630, poz. $\mathrm{j} / 1-5)$.

${ }_{130}$ ACM, Rękop. bibl., sygn. 630, fol. 174r-176r; Katalog Archiwum..., s. 257 (nr 630, poz. h).

131 ACM, Rękop. bibl., sygn. 630, fol. 22r-v; Katalog Archiwum..., s. 255-256 (nr 631, poz. a/2). W tekście datę tego listu określono na 6 września $1471 \mathrm{r}$. Według Codex Diplomaticus Regni Poloniae Et Magni Dvcatus Litvaniae Macieja Dogiela (t. 1, cz. 1, Wilno 1758, s. 60-61, nr XIX) data to 15 września 1471 r.; por. Słownik władców Europy średniowiecznej, red. J. Dobosz, M. Serwański, Poznań 1998, s. 257-260.

${ }_{132}$ Por. ACM, Rękop. bibl., sygn. 630 z W. Heinemeyer, Studien zur Geschichte der gotischen Urkundenschrift, Köln-Graz 1962, tab. 10/11, 1/13, 14/15, 16/17; A. Gieysztor, dz. cyt., s. 133-136; W. Semkowicz, Paleografia ..., s. 320-325. 
ta pozycja związana z kaznodziejstwem - Sermo de beata virgine Maria ${ }^{133}$ - pochodzi według K. Kaczmarczyka i G. Kowalskiego z lat 1479-1480, o czym świadczą następujące noty z datami: Explicit liber sancti Anshelmi sub anno Domini 1479 in die apostolorum Petri et Pauli oraz Explicit feliciter anno salutifere carnacionis Christi MCCCCLXXX pridie kalendas Aprilis ${ }^{134}$.

Duszpasterstwo Zachował się tekst dotyczący sakramentów De sacramentis veteris et nove legis napisany przez Jana $\mathrm{z}$ Gniezna ${ }^{135}$. Znajduje się w kodeksie z 1464 r., a datację oparto na kolofonie: [Rubro:] Explicit liber sentenciarum scriptus Cracovie per me Johannem de Gnezna filium olim petri dimicatoris Anno domini millesimo quadricentesimo sexagesimo quarto Amen ${ }^{136}$. Kolofon ten prezentujemy poniżej.

Fot. 7

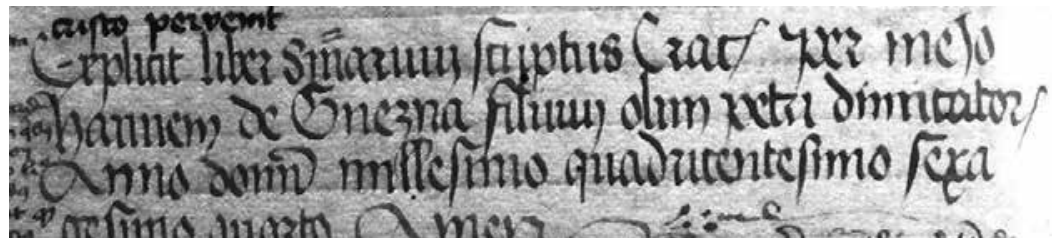

Kolofon Jana z Gniezna z roku 1464. ACM, Rękop. bibl., sygn. 626, fol. $96^{v}$

Ascetyka Zachowała się kopia dzieła Lotara hrabiego Segni (późniejszego papieża Innocentego III) De miseria conditionis humane ${ }^{137}$. Dzieło to, znane też jako Liber de contemptu mundi, sive de miseria humanae conditionis, powstałe między końcem grudnia 1194 a początkiem kwietnia 1195 r., zawiera trzy wątki. Pierwszy dotyczy cielesnej nędzy człowieka, drugi marności jego ambicji, zaś trzeci ukazuje rozkład ludzkiego ciała i potępienie w piekle ${ }^{138}$. Kopia tego dzieła zachowała się w rękopisie datowanym na rok 1463, o czym świadczy nota Sub anno domini Millesimo quadringen-

133 ACM, Rękop. bibl., sygn. 631, fol. 267v-276r; Katalog Archiwum..., s. 258 (nr 631, poz. i).

134 ACM, Rękop. bibl., sygn. 631, fol. 73v (1479) i fol. 265r (1480); Katalog Archiwum..., s. 258 (po dacie $M C C C C L X X X$ znak zapytania wydawców).

135 ACM, Rękop. bibl., sygn. 626, fol. 105r-164v; Katalog Archiwum..., s. 252 (nr 626, poz. c).

136 ACM, Rękop. bibl., sygn. 626, fol. 96v; Katalog Archiwum..., s. 252 (nr 626, poz. c).

137 ACM, Rękop. bibl., sygn. 623, fol. 112r-131v; Katalog Archiwum..., s. 249 (nr 623, poz. g); R. Fischer-Wollpert, Leksykon papieży, Kraków 1990, s. 99.

${ }^{138}$ De Miseria Condicionis Humane [online], <en.wikipedia.org./wiki/De_Miseria Condicionis_Humane>(dostęp 5 I 2016); Encyklopedja Kościelna podtug teologicznej Encyklopedji Wetzera $i$ Weltego z licznemi jej dopetnieniami przy wspótpracownictwie kilkunastu duchownych $i$ świeckich osób wydana..., wyd. ks. M. Nowodworski, Warszawa 1876, t. 8, s. 176; Enciclopedia Cattolica, t. 7: Inno-Mapp, [Roma] 1951, s. 10; Podręczna Encyklopedya Kościelna, opr. ks. S. Gall [i in.], red. ks. Z. Chełmicki, Warszawa 1909, t. 17-18, s. 145; PL, t. 217, col. 701-746; O wzgardzie świata albo nędzy stanu człowieczego Troje ksiąszi /Przez Innocensiusa III przed półczwarta sta lat napisane, a teraz na nowo na polskie przełożone, [b.m.] 1571, tłum. S. Lwowczyk, k. 65. 
tesimo 63 na końcu indeksu dzieła Super de in amorationem et feminarum ${ }^{139}$. Prezentuje ją niżej zamieszczona fotografia.

Fot. 8

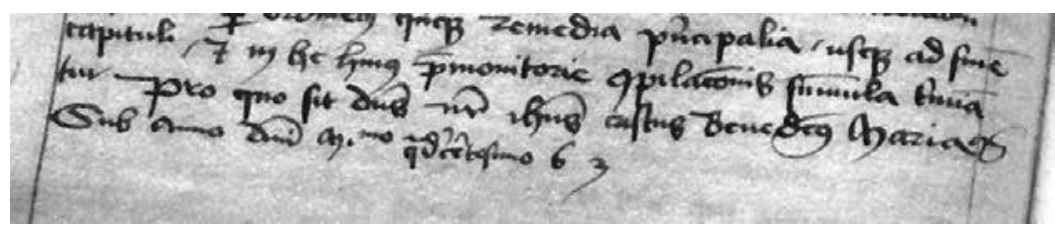

Datacja kodeksu. ACM, Rękop. bibl., sygn. 623, fol 56

(ostatni wiersz na dole)

Ascetyka z moralistyką W wyżej wymienionym kodeksie z $1463 \mathrm{r}$. znajdują się dwa dzieła o takim charakterze. Pierwszym z nich jest Comentarius ascethico-moralis in verba: vinum et mulieres apostotare faciunt sapientes et argunt insensatos ${ }^{140}$. Jest to komentarz ascetyczno-moralny, może bardziej moralny, nawiązujący do Starego Testamentu, a konkretnie do fragmentu Mądrości Syracha czyli Eklezjastyka (19, 2): „Wino i kobiety wykolejają mądrych" "141. Drugie dzieło wiąże się z pierwszym, ponieważ jest to Registrum siue thabula super de in amorationem et feminarum, czyli jego indeks ${ }^{142}$.

Moralistyka Kodeks z 1451 r. zawiera dzieło przepisane przez Piotra z Osuchowa Tractatus de peccato, invidia, ira, avaritia, gula, luxuria, et de castitate $^{143}$, a datacja znajduje się w kolofonie: Explicit laborintus exemplorum Anno Domini MCCCCLI ${ }^{144}$. Ponadto jest także krótka nota: per me Petrum, co może sugerować, że Piotr był kopistą ${ }^{145}$. W kodeksie z $1463 \mathrm{r}$. znajduje się dzieło Dialogus inter eremitam et angelum ${ }^{146}$ oraz dwa traktaty Jakuba z Paradyża: Tractatulus de triplici genere hominum prelatorum activorum et contemplativorum ${ }^{147}$ oraz Tractatus de peccatis mentalibus et

139 ACM, Rękop. bibl., sygn. 623, fol. 56v; Katalog Archiwum..., s. 248 (nr 623, poz. c).

140 ACM, Rękop. bibl., sygn. 623, fol. 30r-55v; Katalog Archiwum..., s. 248 (nr 623, poz. b).

${ }^{141}$ Por. Biblia tysiaclecia. Pismo święte Starego i Nowego testamentu w przekladzie z języków oryginalnych, red. o. A. Jankowski OSB, ks. L. Stachowiak (ST), ks. K. Romaniuk (NT), Poznań 1980.

${ }_{142}$ ACM, Rękop. bibl., sygn. 623, fol. 56r-v; Katalog Archiwum..., s. 248 (nr 623, poz. c).

${ }_{143}$ ACM, Rękop. bibl., sygn. 612, fol. 1r-161r; Katalog Archiwum..., s. 240 (nr 612, poz. a).

144 ACM, Rękop. bibl., sygn. 612, fol. 161r; Katalog Archiwum..., s. 240 (nr 612).

145 ACM, Rękop. bibl., sygn. 612, fol. 168r; Katalog Archiwum..., s. 240-241 (nr 612).

146 ACM, Rękop. bibl., sygn. 623, fol. 1r-29v (Datacja zawarta w rękopisie, fol. 56v: 1463); Katalog Archiwum..., s. 247-248 (nr 623, poz. a).

${ }_{147}$ ACM, Rękop. bibl., sygn. 623, fol. 57r-73v (na końcu tekstu - fol. 73v - imię Nicolaus, być może kopisty); Katalog Archiwum..., s. 248 (nr 623, poz. d); Z. Domżał, A. Wałkówski, Imię róży inaczej..., s. 144. 
mortalibus $^{148}$. Ponadto mamy do czynienia z utworami Processus ${ }^{149}$ i $Q u i$ in vinorum diversitate $[\ldots]^{150}$ - króciutkim tekstem moralizatorskim potępiającym pijaństwo i chwalącym trzeźwość. W księdze z lat 1479-1480151 zachowała się kopia dzieła świętego Bernarda z Clairvaux Soliloquium ${ }^{152}$.

Moralistyka. Pokuta W tym przypadku chodzi o dzieło Jana Chryzostoma De reparatione lapsi ${ }^{153}$.

Mistyka Zachował się kodeks z lat $1479-1480^{154}$, który zawiera dwa dzieła: pierwsze - św. Bonawentury Liber meditationum sive opinionum domini cardinalis ac doctoris Bonaventure, qui dicitur ymago vite eterne ${ }^{155}$, zaś drugie - św. Bernarda z Clairvaux Contemplacio devoti Bernardi abatis Clare Vallis ${ }^{156}$.

Twórczość obituarna (memoratywna) M. Kaczmarek zalicza do niej nekrologi, w stosunku do których używa określenia „liturgia memoratywna" 157 . W naszym przypadku proponujemy poszerzenie tej kategorii także o inne utwory, które wspominają zmarłych w aspekcie eschatologicznym. Do tego typu tekstów możemy zaliczyć dzieło św. Bernarda z Clairvaux Planctus pro Humberto monacho defuncto ${ }^{158}$, znajdujące się w kodeksie datowanym po $1471 \mathrm{r}^{159}$

Hagiografia. Żywoty świętych W rękopisie sporządzonym przez Mikołaja z Krakowa w latach 1464-1471 znajduje się Vita sancti Stanislai Craco-

148 ACM, Rękop. bibl., sygn. 623, fol. 73v-87v; Katalog Archiwum..., s. 248 (nr 623, poz. e); Z. Domżał, A. Wałkówski, Imię róży inaczej..., s. 144; ks. J. Fijałek, Mistrz Jakub z Paradyża i Uniwersytet Krakowski w okresie Soboru Bazylejskiego, t. 2, Kraków 1900, s. 269; o twórczości Jakuba por. także D. Mertens, Untersuchungen zur Rezeption der Werke des Kartäuser Jacob von Paradies (1381-1465), Göttingen 1976, s. 146-165.

149 ACM, Rękop. bibl., sygn. 623, fol. 132r-147v; Katalog Archiwum..., s. 249 (nr 623, poz. h).

${ }_{150}$ ACM, Rękop. bibl., sygn. 630, fol. 1r, tytuł na podstawie incipitu: Qui venit in nomine domini. Qui in vinorum diuersitate et habundatia est sobrius [...].

${ }_{151}$ ACM, Rękop. bibl., sygn. 631, noty z datacjami - fol. 73v (1479) i fol. 265r (1480); Katalog Archiwum..., s. 258 (nr 631).

152 ACM, Rękop. bibl., sygn. 631, fol. 107r-119r; Katalog Archiwum..., s. 258 (nr 631, poz. f).

153 ACM, Rękop. bibl., sygn. 623, fol. 89r-111r; Katalog Archiwum..., s. 248-249 (nr 623, poz. f).

154 ACM, Rękop. bibl., sygn. 631, fol. 73v - nota zawierająca rok 1479: Explicit liber sancti Anshelmi sub anno Domini 1479 in die apostolorum scilicet Petri et Pauli, fol. 265r - nota zwierająca rok 1480: Explicit feliciter anno salutifere carnacionis Christi MCCCCLXXX pridie kalendas Aprilis; Katalog Archiwum..., s. 258 (nr 631) - po dacie MCCCCLXXX wydawcy umieścili znak zapytania, ale nie wyjaśnili jego znaczenia.

155 ACM, Rękop. bibl., sygn. 631, fol. 1r-59r; Katalog Archiwum..., s. 258 (nr 631, poz. a).

156 ACM, Rękop. bibl., sygn. 631, fol. 119v-144r; Katalog Archiwum..., s. 258 (nr 631, poz. g).

${ }_{157}$ M. Kaczmarek, Rozwój liturgii memoratywnej u cystersów od form prostych do w petni wyksztatconego nekrologu, „Nasza Przeszłość” 1994, t. 83, s. 281-293.

158 ACM, Rękop. bibl., sygn. 630, fol. 28r-31v; Katalog Archiwum..., s. 256 (nr 630, poz. b).

${ }_{159}$ Tamże, s. 255 i 258 - datacja na podstawie najpóźniej datowanego tekstu w kodeksie, tj. listu Kazimierza Jagiellończyka do Macieja Korwina na temat pretensji do korony Węgier z 1471 r.; por. Codex Diplomaticus Regni Poloniae et..., s. 60-61, nr XIX. 
viensis episcopi et martiris ${ }^{160}$. Natomiast w kodeksie spisanym po $1471 \mathrm{r}$. do zbioru kazań włączono Vita sancti Adalberti atque sancti Georgii ${ }^{161}$.

Hagiografia. Opisy męczeństwa Do zbioru kazań we wspomnianym kodeksie dodano Passio beate Agnetis virginis pióra świętego Ambrożego (wg oryginału: Passio beate Agnetis virginis edita a beato Ambrosio episcopo) ${ }^{162}$.

Hagiografia. Opisy cudów W księdze z lat 1464-1471 zachowały Miracula martiris Stanislai, spisane - zgodnie z kolofonem - przez Mikołaja z Krakowa ${ }^{163}$. Tekst Miracula Beate Virginis Marie także napisał Mikołaj ${ }^{164}$, a o jego autorstwie wiemy z kolofonu rubro: Nicolaus de claratumba monachus ${ }^{165}$. To dzieło zachowało się w kodeksie powstałym między 1471 a 1490 r. ${ }^{166}$ Inny tego rodzaju utwór to Dialogus miraculorum Cezarego z Heisterbach ${ }^{167}$, jest w księdze z 1452 r., jest w niej data roczna $^{168}$.

Literatura pasyjna Zachował się kodeks z lat 1479-1480169, który zawiera Liber Anshelmi de passione Domini pióra św. Anzelma ${ }^{170}$ oraz św. Bernarda z Clairvaux Contemplacio beati Bernardi super septem horas diei de passione Domini ${ }^{171}$ i Cogitatio Bernhardi de passione Domini ${ }^{172}$.

${ }^{160}$ ACM, Rękop. bibl., sygn. 624, pag. 604-618 (o tym, że spisał go Mikołaj z Krakowa, świadczy kolofon - pag. 844: Explicit liber primus per me fratrem Nicolaum de Cracovia scriptus ad honorem dei omnipotentis et beate Marie virginis); Katalog Archiwum..., s. 250 (nr 624, poz. c oraz końcowe uwagi zawierające kolofon Mikołaja).

${ }^{161}$ ACM, Rękop. bibl., sygn. 630, fol. 141v-142v; Katalog Archiwum..., s. 255, 257 (nr 630, poz. f/5), 258. Chronologię księgi określono na podstawie najpóźniej datowanego w niej tekstu, to jest wspomnianego wyżej listu Kazimierza Jagiellończyka; por. Codex Diplomaticus Regni Poloniae et..., s. 60-61, nr XIX.

${ }^{162}$ ACM, Rękop. bibl., sygn. 630, fol. 148v-150v (oryginalna wersja tytułu na podstawie incipitu - fol. 141v: Incipit passio beato Agnetis virginis edita a beato Ambrosio episcopo); Katalog Archiwum..., s. 257 (nr 630, poz. f/7).

163 ACM, Rękop. bibl., sygn. 624, pag. 618-623; Katalog Archiwum..., s. 250 (nr 624, poz. d).

164 ACM, Rękop. bibl., sygn. 625, pag. 772-851 (w oryginale pag. 772, rubro: Sequitur miracula de beatissima virigne maria); Katalog Archiwum..., s. 252 (nr 625, poz. b).

165 ACM, Rękop. bibl., sygn. 625, pag. 851; Katalog Archiwum..., s. 252; patrz fot. 6.

${ }^{166} \mathrm{O}$ dacie post quem mówi informacja dotycząca pielgrzymki do relikwii błogosławionej Katarzyny, która miała miejsce w 1471 r. (ACM, Rękop. bibl., sygn. 625, pag. 709). Jest to wydarzenie mające miejsce przed spisaniem kodeksu lub najpóźniej w trakcie pracy nad nim i dlatego przyjmujemy ten rok jako datę post quem. Natomiast data ante quem to rok 1490, który jest podany w dodatku do kolofonu Mikołaja z Krakowa i mówi o czasie powstania kodeksu (por. fot. 6). Inaczej - na lata 1464-1471 datuje - go Katalog Archiwum..., s. 250 i 252 (nr 625).

${ }_{167}$ ACM, Rękop. bibl., sygn. 618, fol. 1r-96r; Katalog Archiwum..., s. 244 (nr 611, poz. a).

168 ACM, Rękop. bibl., sygn. 618, fol. 93r-MCCCCLII; Katalog Archiwum..., s. 245.

169 ACM, Rękop. bibl., sygn. 631, fol. 73v (nota zawierająca rok 1479), fol. 265r (nota zwierająca rok 1480); Katalog Archiwum..., s. 258 (nr 631).

170 ACM, Rękop. bibl., sygn. 631, fol. 61r-73r; Katalog Archiwum..., s. 258 (nr 631, poz. b); Encyklopedja Kościelna ..., t. 1, Warszawa 1873, s. 297 (tu dzieło to wymieniono jako De passione Christi).

171 ACM, Rękop. bibl., sygn. 631, fol. 74r-99r; Katalog Archiwum..., s. 258 (nr 631, poz. c).

172 ACM, Rękop. bibl., sygn. 631, fol. 99v-103r; Katalog Archiwum..., s. 258 (nr 631, poz. d). 
Poezja i pieśni na motywach religijnych. W kodeksie powstałym po 1467 r. $^{173}$ znajduje się wiersz De vita Salomonis ${ }^{174}$. Dzieło to nie zostało zaopatrzone w informację o autorze, zaś Konstanty Michalski i Tadeusz Sinko wymieniają ten wiersz, ale nie zajmują się nim, ponieważ uznali go za znajdujący się poza granicami ich tematu badawczego ${ }^{175}$. Natomiast rękopis spisany między 1479 i 1480 r. ${ }^{176}$ zawiera pieśń św. Bernarda z Clairvaux Iubilus dulcis Bernhardi de nomine Jesu ${ }^{177}$.

Teologia. W kodeksie z $1451 \mathrm{r}^{178}$ zachowało się dzieło De resurrectione mortuorum $^{179}$. W późniejszym manuskrypcie z $1460 \mathrm{r}^{180}{ }^{1 \text { znajduje się Opiniones }}$ super varias questiones theologicas pióra Mikołaja Kozłowskiego, doktora teologii i profesora wydziału teologicznego uniwersytetu w Krakowie oraz Dziersława Borzymowskiego, dwukrotnego rektora tejże uczelni ${ }^{181}$. Następne dzieło De festis a principio Adventus usque ad sanctam Trinitatem occurentibus ${ }^{182}$ jest

${ }^{173}$ ACM, Rękop. bibl., sygn. 629 - podstawą datacji jest zawarta w kodeksie kopia bulli papieża Pawła II, wydanej w Rzymie 15 maja 1467 r. dla Rudolfa, biskupa Lavantu, nuncjusza Stolicy Apostolskiej w Czechach, Liwonii, Miśni, Polsce i Prusach - pag. 290-292. Jest to najpóźniej datowany tekst w opracowywanym kodeksie i dlatego można go przyjąć za wyznacznik post quem jego czasu powstania; Katalog Archiwum..., s. 253-255 (bulla wymieniona na s. 254, poz. o) przyjmuje taką datację; P.B. Gams, Series episcoporum Ecclesiae catholicae, quotquot innotuerunt a beato Petro apostolo. A multis adjutus..., Ratisbonae 1873, s. 264, 285; K. Dola, Rudolf z Rüdesheimu, Rudolf Hecker, [w:] Encyklopedia Katolicka, t. 17, red. E. Gigilewicz i in., Lublin 2012, kol. 555-556; J. Radziszewska, Działalność dyplomatyczna Rudolfa von Rüdesheim, ,Zeszyty Naukowe Wyższej Szkoły Pedagogicznej w Katowicach. Prace Historyczne” 1964, nr 1 (22), s. 24-25; Politische Correspondenz Breslaus im Zeitalter Georgs von Podiebrad. Zugleich als Urkundliche Belege zu Eschenloers Historia Wratislaviensis. Names des Vereins für Geschichte und Alterthum Schlesiens. Abt 2: 1463-1469, hrsg. von H. Markgraf, Breslau 1874, s. 233-235.

${ }_{174}$ ACM, Rękop. bibl., sygn. 629, pag. 285; Katalog Archiwum..., s. 254 (nr 629, poz. 1).

${ }^{175}$ K. Michalski, T. Sinko, Przyczynki z kodeksu mogilskiego do dziejów oświaty w Polsce w XV wieku, Kraków 1917, s. 3, 11.

${ }^{176}$ ACM, Rękop. bibl., sygn. 631 - o powstaniu rękopisu w tym czasie świadczy datacja kodeksu w postaci dwóch wzmianek - fol. 73v (informacja zawierająca rok 1479), fol. 265r (rok 1480); Katalog Archiwum..., s. 258 (nr 631) przyjmuje taką datację.

177 ACM, Rękop. bibl., sygn. 631, fol. 103v-106r; Katalog Archiwum..., s. 258, (nr 631, poz. e).

178 ACM, Rękop. bibl., sygn. 612, datacja rękopisu MCCCCLI - fol. 161r; Katalog Archiwum..., s. 240-241 (nr 612).

179 ACM, Rękop. bibl., sygn. 612, fol. 162r-163r; Katalog Archiwum..., s. 240 (nr 612, poz. b).

180 ACM, Rękop. bibl., sygn. 621, fol. 287r; Katalog Archiwum..., s. 246 (nr 621). Datacja według tego Katalogu przyjęta bez uzasadnienia. Zapewne została oparta o rok 1460 zapisany na końcu dzieła Macieja z Łowicza Liber granarii per Mathiam de Lowycz sub anno 1460. O Macieju z Łowicza zob. K. Bracha, Casus pulchri de vitandis erroribus conscientiae purae. Orzeczenia kazuistyczne kanonistów i teologów krakowskich z XV wieku, Warszawa 2013, s. 62.

${ }_{181}$ ACM, Rękop. bibl., sygn. 621, fol. 289r-312v (oryginalny tytuł: Opiniones Nicolai Kozłowski, doctoris theologie, et Derslai Borzymowski, doctoris iuris, super varias questiones theologicas); Katalog Archiwum..., s. 246 (nr 621, poz. b); Podręczna Encyklopedya Kościelna, t. 21-22, Warszawa 1910, s. 379; Kultura Polski średniowiecznej XIV-XV wieku, red. B. Geremek, Warszawa 1997, s. 582; T. Michałowska, Literatura polskiego średniowiecza. Leksykon, Warszawa 2011, s. 525; K. Bracha, dz. cyt., s. 34, 37, 40 i 73-75.

${ }_{182}$ ACM, Rękop. bibl. sygn. 624, fol. 11r-604r; Katalog Archiwum..., s. 250 (nr 624, poz. b). 
w kodeksie datowanym przez wydawców Katalogu... na lata 1464-1471 ${ }^{183}$. Natomiast w manuskrypcie powstałym po $1467 \mathrm{r}^{184}$ zapisano rzadko spotykany traktat teologiczny De septem donis Spiritus Sancti ${ }^{185}$. Ta sama księga zawiera dzieło św. Bonawentury Ad honorem gloriose et indiuidue Trinitatis et ad reuerenciam excellentissimi sacramenti corporis et sanguinis Domini nostri Ihesu Christi $^{186} \mathrm{i}$ anonimowy tekst: Vnum crede deum ${ }^{187}$. Także św. Bonawentura jest autorem Speculum anime, traktatu nawiązującego do wizji duszy, jej nierozerwalnego związku z ciałem, nad którym sprawuje ona kontrolę woli oraz intelektu ${ }^{188}$. Traktat ten jest w manuskrypcie powstałym po $1471 \mathrm{r} .{ }^{189} \mathrm{~W}$ tym samym kodeksie znajduje się zaliczane przez literaturę przedmiotu do rozpraw i pomniejszych traktatów dzieło św. Tomasza z Akwinu Super Symbolum Apostolorum ${ }^{190}$ oraz Hugona z Folieto De edificatione liber quartus ${ }^{191}$. Następne dzieło - Speculum

${ }^{183}$ Datacji tej nie uzasadniono. Zapewne wiąże się ona $\mathrm{z}$ następną księgą sporządzoną według G. Kowalskiego i K. Kaczmarczyka również przez Mikołaja z Krakowa, którą wydawcy datują także na lata 1464-1471 - zob. Katalog Archiwum..., s. 250-252 (nr 624 i 625).

${ }^{184}$ Podstawą datacji jest wspomniana wyżej kopia bulli papieża Pawła II. Jest to najpóźniej datowany tekst $\mathrm{w}$ opracowywanym kodeksie i dlatego stanowi wyznacznik post quem czasu powstania rękopisu - ACM, Rękop. bibl. sygn. 629, pag. 290-293; Katalog Archiwum..., s. 253 (nr 629) i 254 (poz. o).

${ }_{185}$ ACM, Rękop. bibl., sygn. 629, pag. 1-38; Katalog Archiwum..., s. 253 (nr 629, poz. a); K. Michalski, T. Sinko, dz. cyt., s. 5.

${ }_{186}$ ACM, Rękop. bibl., sygn. 629, pag. 255-265 (tytuł na podstawie incipitu, pag. 255: [Rubro:] $A$ [nigro:]d honorem gloriose et indiuidue trinitatis et ad reuerenciam excellentissimi sacramenti corporis et sanguinis domini nostri Ihesu Christi; Katalog Archiwum..., s. 254 (nr 629, poz. h); K. Michalski, T. Sinko, dz. cyt., s. 5-6 (przy czym badacze tylko wskazują na miejsce dzieła w rękopisie, podają incipit oraz eksplicit; nie odnoszą się do autorstwa, ani tytułu).

187 ACM, Rękop. bibl., sygn. 629, pag. 265-270; Katalog Archiwum..., s. 254 (nr 629, poz. i); K. Michalski, T. Sinko, dz. cyt., s. 3 (badacze tylko wymieniają tę pozycję i nie identyfikują autora oraz tytułu; podają jedynie jej miejsce w rękopisie, incipit oraz eksplicit).

188 ACM, Rękop. bibl., sygn. 630, fol. 85r-94v; Katalog Archiwum..., s. 256 (nr 630, poz. d); H. Wegner, Bonawentura, [w:] Encyklopedia Katolicka, t. 2, red. F. Gryglewicz, R. Łukaszyk, Z. Sułowski, Lublin 1976, s. 783; Encyklopedja Kościelna..., wyd. ks. M. Nowodworski, t. 2, Warszawa 1873, s. 481.

189 Datacja na podstawie najpóźniej datowanego tekstu w kodeksie, to jest wspomnianego wyżej listu Kazimierza Jagiellończyka do Macieja Korwina: ACM, Rękop. bibl., sygn. 630, fol. 22r-v; Katalog Archiwum..., s. 255-256 (nr 630, poz. a/2).

${ }^{190}$ Pełny tytuł wg oryginału: Expositio simboli secundum fratrum Thomam de Aquino-ACM, Rękop. bibl., sygn. 630, fol. 113r-127v; Katalog Archiwum..., s. 256-257 (nr 630, poz. f/3); Tomasz z Akwinu, [w:] Encyklopedia Kościelna podtug Teologicznej Encyklopedii Wetzera $i$ Weltego $z$ licznemi jej dopetnieniami przy wspótpracownictwie kilkunastu duchownych i świeckich osób..., wyd. ks. M. Nowodworski, t. 28, Warszawa 1905, s. 565-566; J. Szczęsna, Tomasz z Akwinu, [w:] Encyklopedia Katolicka, t. 19, red. E. Gigilewicz, Lublin 2013, kol. 849; por. Catalogus manu scriptorum codicum medii aevi Latinorum signa 180-260 comprehendens = Katalog tacińskich rękopisów średniowiecznych obejmujący kodeksy 180-260, compositus a C.C. Jażdżewski = opr. K.K. Jażdżewski, Wrocław 1982, s. 232, nr 240 (I F 213), poz. 1.

${ }_{191}$ ACM, Rękop. bibl., sygn. 630, fol. 176v-199r, pełny tytuł: Liber quartus Hugonis de edificacione na podstawie incipitu: Incipit liber quartus Hugonis de edificacione ubi et unde, cum quo et qualiter edificanda sit domus domini; Katalog Archiwum..., s. 257 ( $\mathrm{nr}$ 630, poz. g). 
Beate Mariae Virginis - stworzył św. Bonawentura ${ }^{192}$, a kopię tekstu zawiera kodeks datowany na lata $1479-1480^{193}$.

Teologia. Chrystologia. W księdze z 1464 r. ${ }^{194}$ znajduje się tekst De Christo homine facto ${ }^{195}$. Natomiast manuskrypt powstały po $1476 \mathrm{r} .{ }^{196}$ zawiera kopię listu Samuela Jehudy, czyli rabiego Samuela, do Izaaka ben Jakuba al Phasi: Epistola Rabi Samuelis missa ad Rabi Ysaac ${ }^{197}$. Zdaniem autorów opracowań naukowych autorem listu był żydowski konwertyta Samuel Jehuda, żyjący w tym samym czasie co adresat listu i twórca pierwszego kompendium do Talmudu Jishak [Izzak, Ysaac] ben Jakub al Phasi, czyli na przełomie XI i XII w. Tłumaczem był natomiast Alfons Buenhombre (Bonus Homo), dominikaninz Toledo. K. Michalski i T. Sinko przyjmują za wcześniejszą literaturą czas thumaczenia na 1336, zaś wydawcy Katalogu ... - na 1339 r. ${ }^{198}$ Niewielka to różnica i biorąc pod uwagę okres życia obu żydowskich korespondentów (XI/XII w.), XIV stulecie jako czas przekładu jest możliwy. Sam Samuel Jehuda napisał szereg dzieł misyjnych służących nawracaniu Żydów ${ }^{199}$.

Teologia. Eschatologia. Zachował się traktat brata $N$ z klasztoru św. Doroty Dziewicy w Wiedniu Tractatulus de quatuor de novissimis et de tribus necessariis cuilibet proficere volenti, który wyjaśnia prawdę o czterech rzeczach ostatecznych: śmierci, sądzie, niebie i piekle ${ }^{200}$. Autor był przełożonym tego klasztoru, co wynika z początkowych słów: Cum in prefato monasterio indignus ego prioratus officio fungere ${ }^{201}$. Dzieło mogło powstać między rokiem 1438 a 9 października 1454 r., ponieważ jest ono dedykowane Sylwestrowi Pfligerowi, biskupowi Chiemsee, a na ten czas przypadł jego pontyfikat,

192 ACM, Rękop. bibl., sygn. 631, fol. 146r-265r; Katalog Archiwum..., s. 258 (nr 631, poz. h).

193 Świadczą o tym daty wpisane do kolofonów - ACM, Rękop. bibl., sygn. 631, fol. 73v (1479) i fol. 265r (1480); Katalog Archiwum..., s. 258 (nr 631).

194 ACM, Rękop. bibl., sygn. 626 - datacja została oparta na kolofonie pierwszego dzieła - Liber sentenciarum, fol. 96v, [rubro]: Explicit liber sentenciarum scriptus Cracovie per me Johannem de Gnezna filium olim Petri dimicatoris Anno domini millesimo quadrincentesimo sexagesimo quarto Amen; por. Katalog Archiwum..., s. 252 (nr 626, poz. a).

195 ACM, Rękop. bibl., sygn. 626; Katalog Archiwum..., s. 252 (nr 626, poz. d) - według jego wydawców pełny tytuł brzmi: De Christo homine facto, de virtutibus et sacramentis, ale dzieło zachowało się bez początku.

196 ACM, Rękop. bibl., sygn. 629, pag. 290-292 - najpóźniej datowany tekst w opracowywanym kodeksie, który można przyjąć jako wyznacznik post quem czasu powstania woluminu jest to wymieniona wyżej kopia bulli papieża Pawła II; Katalog Archiwum..., s. 255 (nr 629) i 266 (poz. o). O datacji tej księgi pisaliśmy już wyżej.

197 Pełny tytuł: Epistola Rabi Samuelis missa ad Rabi Ysaac magnum doctorem iudeorum [...] translata de arabico in latinum per fratrem Alfonsum boni hominis hyspanum ordinis predictorum sub anno 1339 - ACM, Rękop. bibl., sygn. 629, pag. 351-379; Katalog Archiwum..., s. 255 (nr 629, poz. w).

${ }_{198}$ K. Michalski, T. Sinko, dz. cyt., s. 4, 6-7; Katalog Archiwum..., s. 255 (nr 629, poz. w).

199 K. Michalski, T. Sinko, dz. cyt., s. 6-7.

200 ACM, Rękop. bibl., sygn. 630, fol. 32r-84v; Katalog Archiwum..., s. 256 (nr 630, poz. c).

201 ACM, Rękop. bibl., sygn. 630, fol. 32r. 
o czym świadczą początkowe słowa: Reuerendo in Christo Patri et Domino suo gratiosissimo Domino Siluestro Chimenensis ecclesie presuli Dignissimo ${ }^{202}$. Omówione dzieło znajduje się w kodeksie powstałym po $1471 \mathrm{r}^{203}$

Teologia moralna. Dwa dzieła Jakuba z Paradyża zachowały się w księdze pochodzącej z $1463 \mathrm{rr}^{204}$ : Oculus considerationis religiosorum ${ }^{205} \mathrm{i}$ Tractatus de profectu in vita spirituali ${ }^{206}$. Kopia tego drugiego dzieła jest także w rękopisie powstałym po $1467 \mathrm{r}^{207} \mathrm{~W}$ tym samym manuskrypcie znajdują się trzy kopie innych dzieł Jakuba: Planctus peccatorum ${ }^{208}$, De veritate dicenda aut tacenda ${ }^{209}$ oraz De mitigacione passionis iracundie ${ }^{210}$. Kodeks powstały po $1471 \mathrm{r}^{211} \mathrm{za}-$ wiera kopię wspomnianego już Planctus peccatorum ${ }^{212}$ oraz innego dzieła przypisywanego Jakubowi z Paradyża - Speculum amatorum mundi $i^{213}$.

Analiza piśmiennictwa sakralnego średniowiecznej biblioteki klasztoru cystersów w Mogile wskazuje na dominację kazań, których zachowało się łącznie 168 pozycji ${ }^{214}$. Duży udział kaznodziejstwa nie powinien dziwić. Wcześniejsze

${ }^{202}$ Jak wyżej; P.B. Gams, dz. cyt., s. 267.

${ }^{203}$ Świadczy o tym najpóźniej datowany tekst w kodeksie - list Kazimierza Jagiellończyka do Macieja Korwina z 1471 r. - ACM, Rękop. bibl., sygn. 630, fol. 22r-v; Katalog Archiwum..., s. 253-254 (nr 630, poz. a/2). O datacji tej księgi pisaliśmy już wyżej.

${ }^{204}$ ACM, Rękop. bibl., sygn. 623 - datacja podana w rękopisie, fol. 56v: Sub anno domini Millesimo quadringentesimo 63 na końcu indeksu [...] Super de in amorationem et feminarum; Katalog Archiwum..., s. 248 (sygn. 623, poz. c).

${ }^{205}$ ACM, Rękop. bibl., sygn. 623, fol. 148r-206r; Katalog Archiwum..., s. 249 (nr 623, poz. i); Z. Domżał, A. Wałkówski, Imię róży inaczej..., s. 144; ks. J. Fijałek, dz. cyt., s. 228.

${ }^{206}$ W oryginale autor: Jacobus Cartusiensis, a tytuł: Tractatus de profectu in vita spirituali et intencionis hominis - ACM, Rękop. bibl., sygn. 623, fol. 206r-219r; Katalog Archiwum..., s. 249 (nr 623, poz. j); Z. Domżał, A. Wałkówski, Imię róży inaczej..., s. 142, 144; ks. J. Fijałek, dz. cyt., s. 274-275.

${ }^{207}$ Tytuł w oryginale: De profectu in vita spirituali et interiori hominis composicione tractatus eiusdem [Jakub z Paradyża] - ACM, Rękop. bibl., sygn. 629, pag. 166-177; datacja oparta o kopię bulli papieża Pawła II, wydanej w 1467 r., pag. 290-292 (o datacji tej księgi pisaliśmy już wyżej); Katalog Archiwum..., s. 253 (nr 629, poz. c) i 254 (poz. o); Z. Domżał, A. Wałkówski, Imię róży inaczej..., s. 142, 144; ks. J. Fijałek, dz. cyt., s. 274-275.

${ }^{208}$ ACM, Rękop. bibl., sygn. 629, pag. 177-187; Katalog Archiwum..., s. 253 (nr 629, poz. d); ks. J. Fijałek, dz. cyt., s. 276; Z. Domżał, A. Wałkówski, Imię róży inaczej..., s. 144.

209 ACM, Rękop. bibl., sygn. 629, pag. 212-238; Katalog Archiwum..., s. 254 (nr 629, poz. f); ks. J. Fijałek, dz. cyt., s. 270; Z. Domżał, A. Wałkówski, Imię róży inaczej..., s. 144.

210 ACM, Rękop. bibl., sygn. 629, pag. 293-311; Katalog Archiwum..., s. 254 (nr 629, poz. p); ks. J. Fijałek, dz. cyt., s. 267-268; Z. Domżał, A. Wałkówski, Imię róży inaczej..., s. 144.

211 Najpóźniej datowany tekst w kodeksie to list Kazimierza Jagiellończyka do Macieja Korwina z 1471 r. - ACM, Rękop. bibl., sygn. 630, fol. 22r-v; Katalog Archiwum..., s. 255-256 (nr 630, poz. a/2) - o datacji tej księgi pisaliśmy już wyżej.

212 ACM, Rękop. bibl., sygn. 630, fol. 163r-173v; Katalog Archiwum..., s. 257 (sygn. 630, poz. g).

${ }^{213}$ W oryginale autor: Jacobus de Paradiso - ACM, Rękop. bibl., sygn. 630, fol. 94v-103r; Katalog Archiwum..., s. 256 (nr 630, poz. e); ks. J. Fijałek, dz. cyt., s. 329 uważa autorstwo Jakuba z Paradyża za wątpliwe.

${ }^{214}$ BCzart., Dz. Rkp., sygn. 3734 III, pag. 3-114; Tymczasowy katalog..., sygn. 3734 III; ACM, Rękop. bibl., sygn. 618, fol. 97r-109r, sygn. 630, fol. 107r-112v, 135r-141r, 143r-148r, 152r-162v, 174r-176r, 199r-206v; Katalog Archiwum..., s. 240 (nr 610 a, poz. a), 244-245 (nr 618, poz. b), 256-259 (nr 630, poz. f/1, 2, 4, 6, 8, 9, poz. h, poz. j/1-5). 
badania naukowe dowiodły, że w bibliotekach średniowiecznych i w piśmiennictwie sakralnym cystersów kaznodziejstwo było reprezentowane dość licznie ${ }^{215}$. Gromadzono również starannie teksty teologiczne (18 pozycji) ${ }^{216}$, co także stanowiło praktykę powszechną jeśli chodzi o biblioteki klasztorne, w tym - cysterskie $^{217}$. Licznie kopiowano dzieła związane z Biblią (Stary Testament, egzegeza, apokryfy) - zachowało się aż dziewięć pozycji ${ }^{218}$. Jest to zrozumiałe, ponieważ chrześcijaństwo stanowi religię Świętej Księgi ${ }^{19}$. Obecność pokaźnej reprezentacji tekstów związanych z Pismem Świętym była normą w bibliotekach zakonnych i sakralnym piśmiennictwie cystersów ${ }^{220}$. Niewiele mniej - osiem pozycji - liczą dzieła moralistyki i pokuty ${ }^{221}$, także reprezentatywne w bibliotekach klasztornych i u cystersów ${ }^{222}$. Znaczącą liczbę sześciu dzieł notujemy w zakresie liturgii ${ }^{223}$, ponieważ cystersi (i nie tylko) kładli nacisk na tę formę aktywności, a księgi liturgiczne są często spotykane $\mathrm{w}$ gromadzonym przez nich piśmiennictwie $^{224}$. Literatura hagiograficzna obejmowała zarówno żywoty świętych, jak i opisy cudów i męczeństwa - w spuściźnie średniowiecznej biblioteki cyster-

${ }^{215}$ Por. np. A. Wałkówski, Skryptoria cystersów filiacji portyjskiej..., s. 103; tenże, Piśmiennictwo sakralne..., s. 380-381; tenże, Biblioteka klasztorna jako miejsce..., s. 122-123, 134, 138.

${ }^{216}$ ACM, Rękop. bibl., sygn. 612, 162r-163r, sygn. 621, fol. 289r-312v, sygn. 624, fol. 11r-604r, sygn. 629, pag. 1-38, pag. 255-270, sygn. 630, fol. 85r-94v; Katalog Archiwum..., s. 241 (nr 612, poz. b), 246 (nr 621, poz. b), 250 (nr 624, poz. b), 253-254 (nr 629, poz. a, h, i), s. 256 (nr 630, poz. d); teologia moralna: ACM, Rękop. bibl., sygn. 623, fol. 148r-219r, sygn. 629, pag. 166-187, 212-238, 293-311, sygn. 630, fol. 94v-103r, 163r-173v; Katalog Archiwum..., s. 249 (nr 623, poz. i, j), 253-254 (nr 629, poz. c, d, f, p), 257 (nr 630, poz. e, g); chrystologia: ACM, Rękop. bibl., sygn. 626, pag. 290-292, sygn. 629, pag. 351-379; Katalog Archiwum..., s. 252 (nr 626, poz. d), 255 (nr 629, poz. w); eschatologia: ACM, Rękop. bibl., sygn. 630, fol. 32r-84v; Katalog Archiwum..., s. 256 (nr 630, poz. c).

${ }^{217}$ Por. w tej sprawie A. Wałkówski, Biblioteka klasztorna jako miejsce..., s. 123-125.

${ }^{218}$ Stary Testament: ACM, Rękop. bibl., sygn. 615, fol. 1r-83v, 116v-204v; Katalog Archiwum..., s. 242-243 (nr 615, poz. a, b, c, e); egzegeza: ACM, Rękop. bibl., sygn. 613-617, sygn. 627, fol. fol. 3r-353v; Katalog Archiwum..., s. 241-244 (nr 613-617), 252 (nr 627, poz. a, b); apokryfy: ACM, Rękop. bibl., sygn. 614, fol. 307r; Katalog Archiwum..., s. 242 (nr 614, poz. f).

${ }^{219}$ E. Potkowski, Książka w kręgu sacrum..., s. 54-57.

220 A. Wałkówski, Skryptoria cystersów filiacji portyjskiej..., s. 106; tenże, Piśmiennictwo sakralne..., s. 383, 387 i 389; tenże, Biblioteka klasztorna jako miejsce..., s. 118-119.

${ }^{221}$ ACM, Rękop. bibl., sygn. 612, fol. 1r-161r; Katalog Archiwum..., s. 240 (nr 612, poz. a); ACM, Rękop. bibl., sygn. 623, fol. 1r-29v, 57r-73v, 73v-87v, 132r-147v, sygn. 630, fol. 1r, sygn. 631, fol. 107r-119r; Katalog Archiwum..., s. 247-249 (nr 623, poz. a, d, e, h), 258 (nr 631, poz. f); moralistyka z pokutą: ACM, Rękop. bibl., sygn. 623, fol. 89r-111r; Katalog Archiwum..., s. 248249 (nr 623, poz. f).

${ }^{222}$ A. Wałkówski, Skryptoria cystersów filiacji portyjskiej..., s. 106-107; tenże, Piśmiennictwo sakralne..., s. 383; tenże, Biblioteka klasztorna jako miejsce..., s. 125-126.

${ }^{223}$ BCzart., Dz. Rkp., sygn. 3789 III, pag. 1-153, sygn. 3734 III, pag. 114-143; ACM, Rękop. bibl., sygn. 610, sygn. 619, fol. 53r-123r i 175r-211r; Tymczasowy katalog..., sygn. 3734 III i 3789 III; Katalog Archiwum..., s. 238-240 (nr 609 b, 610, 619).

${ }^{224}$ A. Wałkówski, Skryptoria cystersów filiacji portyjskiej..., s. 104; tenże, Piśmiennictwo sakralne..., s. 382, 386, 389; tenże, Biblioteka klasztorna jako miejsce..., s. 119-121. 
sów z Mogiły zachowało się także sześć takich dzieł ${ }^{225}$ (znaczący udział tego typu tekstów w piśmiennictwie cysterskim był zjawiskiem typowym ${ }^{226}$ ). Inne profile treściowe są prezentowane skromniej - od jednej do trzech pozycji.

Wśród autorów największy udział mają: P. Hirszberg - 119 pozycji (kazania) ${ }^{227}$, Mikołaj z Krakowa - 39 dzieł (37 kazań ${ }^{228}$, jeden żywot ${ }^{229}$, jeden opis cudów ${ }^{230}$ ) i Jakub z Paradyża - kopie ośmiu traktatów ${ }^{231}$ oraz trzy pozycje św. Bernarda z Clairvaux: po jednej z zakresu mistyki ${ }^{232}$, twórczości memoratywnej $^{233}$ oraz pieśni na motywach religijnych ${ }^{234}$. Pozostali autorzy są reprezentowani przez jedno, góra - dwa dzieła. Wśród nich spotykamy szczególnie wybitnych pisarzy, m.in. Mikołaja z Liry: cztery części dzieła Postilla litteralis super [totam] Bibliam, znanej też jako Postilla litteralis ${ }^{235}$, czy krytykę tego egzegety pióra Pawła arcybiskupa Burgos Additiones ad Postillam Nicolai de Lira (Nicolai Lyrani) ${ }^{236}$, Lotara hrabiego Segni (późniejszego papieża Innocentego III) - ascetyczne dzieło De miseria conditionis humane (inny tytuł: Liber de contemptu mundi, sive de miseria Humanae conditionis) ${ }^{237}$, świętych: Ambrożego Passio beate Agnetis virginis ${ }^{238}$, Jana Chryzostoma De reparatione lapsi ${ }^{239}$ i Tomasza z Akwinu Super Symbolum Apostolorum ${ }^{240}$. Obecność trzech pierwszych najczęściej spotykanych pisarzy nie powinna dziwić. P. Hirszberg był wybitnym opatem klasztoru cystersów w Mogile, wcześniej studiował na Uniwersytecie Krakowskim, a ponadto pełnił obowiązki wizyta-

${ }^{225}$ ACM, Rękop. bibl., sygn. 611 (fol. $2 \mathrm{r}$ - zachowany fragment), sygn. 618, fol. 1r-96r, sygn. 624, pag. 604-623, sygn. 625 , pag. $772-851$, sygn. 630 , fol. $141 \mathrm{v}-142 \mathrm{v}, 148 \mathrm{v}-150 \mathrm{v}$; Katalog Archiwum..., s. 240 (nr 611), 250 (nr 624, poz. c, d), 252 (nr 625, poz. b), 257 (nr 630, poz. f/5, 7).

226 A. Wałkówski, Skryptoria cystersów filiacji portyjskiej..., s. 107-108; tenże, Piśmiennictwo sakralne..., s. 384-385; tenże, Biblioteka klasztorna jako miejsce..., s. 125-126.

${ }^{227}$ BCzart., Dz. Rkp., sygn. 3734 III, pag. 3-114; Katalog Archiwum..., s. 240 (nr 610 a, poz. a); Tymczasowy katalog..., sygn. 3734 III.

${ }^{228}$ ACM, Rękop. bibl., sygn. 625, pag. 3-772; Katalog Archiwum..., s. 251 (nr 625, poz. a/ 1-37).

229 ACM, Rękop. bibl., sygn. 624, pag. 604-618; Katalog Archiwum..., s. 250 (nr 624, poz. c).

${ }^{230}$ ACM, Rękop. bibl., sygn. 624, pag. 618-623; Katalog Archiwum..., s. 250 (nr 624, poz. d).

${ }^{231}$ ACM, Rękop. bibl., sygn. 623, fol. 57r-87v, 148r-219r, sygn. 629, pag. 166-187, 212-238, 293-311, sygn. 630, fol. 22r-v, 94v-103r, 163r-173v; Katalog Archiwum..., s. 248-249 (nr 623, poz. d, e, i, j), 253-257 (nr 629, poz. d, f, p i nr 630, poz. a/2, e, g).

${ }^{232}$ ACM, Rękop. bibl., sygn. 631, fol. 119v-144r; Katalog Archiwum..., s. 258 (nr 631, poz. g).

${ }^{233}$ ACM, Rękop. bibl., sygn. 630, fol. 28r-31v; Katalog Archiwum..., s. 256 (nr 630, poz. b).

${ }^{234}$ ACM, Rękop. bibl., sygn. 631, fol. 103v-106r; Katalog Archiwum..., s. 258, (nr 631, poz. e).

${ }^{235}$ ACM, Rękop. bibl., sygn. 613, 614, 615, 616; Katalog Archiwum..., s. 241-244 (nr 613, 614, $615,616)$

${ }^{236}$ S. Szymik, Mikołaj z Liry..., kol. 1005-1006; P. Królikowski, Pawet z Burgos..., s. 129; ACM, Rękop. bibl., sygn. 617; Katalog Archiwum..., s. 244 (nr 617).

${ }^{237}$ ACM, Rękop. bibl., sygn. 623, fol. 112r-131v; Katalog Archiwum..., s. 249 (nr 623, poz. g);

R. Fischer-Wollpert, Leksykon..., s. 99; De Miseria Condicionis Humane...

${ }^{238}$ ACM, Rękop. bibl., sygn. 630, fol. 148v-150v; Katalog Archiwum..., s. 257 (nr 630, poz. f/7).

239 ACM, Rękop. bibl., sygn. 623, fol. 89r-111r; Katalog Archiwum..., s. 248-249 (nr 623, poz. f).

240 ACM, Rękop. bibl., sygn. 630, fol. 113r-127v; Katalog Archiwum..., s. 256-257 (nr 630, poz. f/3). 
tora klasztorów cysterskich w Polsce oraz Prusach ${ }^{241}$. Jego krewnym był brat Mikołaj z Krakowa, kronikarz klasztorny, który prawdopodobnie zajmował się archiwum oraz biblioteką konwentu ${ }^{242}$. Do stosunkowo licznie kopiowanych należały traktaty Jakuba z Paradyża, zakonnika w Mogile i profesora uniwersytetu w Krakowie ${ }^{243}$. Dominują zatem dzieła pisarzy z klasztoru cystersów w Mogile. Jest to naturalne, ponieważ biblioteka konwentu niejako z urzędu wykazywała zainteresowanie twórczością jego członków. Znaczny udział dorobku św. Bernarda z Clairvaux wynikał z tego, że był on nie tylko szczególnie wybitnym przedstawicielem tego zakonu i generalnie Kościoła w XII stuleciu, autorem szeregu traktatów, kazań i listów ${ }^{244}$, ale dzieła te były charakterystyczne dla piśmiennictwa sakralnego cystersów, podobnie jak np. wspomnianego Jana Chryzostoma ${ }^{245}$. Według R. Witkowskiego dzieła Ojców Kościoła występowały w większości cysterskich księgozbiorów ${ }^{246}$. Zdaniem H. Kuny obecność Tomasza z Akwinu wiązała się z wysoką oceną jego dzieł przez cystersów, do czego przyczynił się już Jan Szczekna, tomista na uniwersytecie krakowskim ${ }^{247}$.

W świetle zachowanych rękopisów widać pewne tendencje dotyczące kolekcjonowania tekstów. Wśród odmian piśmiennictwa sakralnego dominują kazania (168 pozycji). Wysoko lokują się teologia, Biblia z egzegezą, moralistyka, pokuta i liturgia. Jak widać, dominują dzieła związane

${ }^{241}$ A. Ciesielski, Hirszberg Piotr, [w:] PSB, t. 9, Wrocław-Warszawa-Kraków 1960-1961, s. 530; H. Leszczyński, Piotr z Biecza, [w:] PSB, t. 26, Wrocław [i in.] 1981, s. 385; M. Starzyński, Katalog opatów mogilskich..., s. 119-120; R. Skrzyniarz, Piotr Hirszberg, [w:] Encyklopedia Katolicka, t. 15, red. E. Gigilewicz, Lublin 2011, s. 676; Z. Domżał, A. Wałkówski, Imię róży inaczej..., s. 153-155.

${ }^{242}$ F. Uryga, Clarae Tumbae (vulgo Mogila) abbates et scriptores, [w:] Xenia Bernardina. Beiträge zur Geschichte der Cistercienser-Stifte..., Wien 1891, s. 310; W. Kętrzyński, Wstęp do Chronicon monasterii Claratumbensis ordinis Cisterciensis auctore fratre Nicolao de Cracovia, [w:] Monumneta Poloniae Historica, t. 6, wyd. W. Kętrzyński, Kraków 1893, s. 429; H. Kuna, Z dziejów biblioteki OO. Cystersów w Mogile..., s. 50-51; E. Gigilewicz, Mikotaj z Krakowa, [w:] Encyklopedia Katolicka, t. 12, red. E. Ziemann, Lublin 2008, s. 1000; Z. Domżał, A. Wałkówski, Imię róży inaczej..., s 37-40, 155-157.

${ }^{243}$ S.A. Porębski, Jakub z Paradyża - poglady i teksty, Warszawa 1994, s. 17-21, 60; J. Stoś, Mistrz Jakub z Paradyża i ,devotio moderna”. Główne problemy refleksji filozoficzno-teologicznej Jakuba z Paradyża i ich zwiazek z ,devotio moderna”, Warszawa 1997, s. 43; tenże, Jakub z Paradyża, Kraków 2004, s. 11-18, 20-21; K. Ożóg, Uczeni w monarchii Jadwigi Andegaweńskiej i Władysława Jagietly (1384-1434), Kraków 2004, s. 37, 60, 305; Z. Domżał, A. Wałkówski, Imię róży inaczej..., s. 74-75, 132-145; tychże, Działalność i poglądy Jakuba z Paradyża, „Echa Przeszłości” 2015, t. 16, s. 36-41.

${ }^{244}$ S. Kiełtyka, Święty Bernard z Clairvaux, Kraków 1984, s. 43-48; K. Jackiewicz, Św. Bernard - opat z Jasnej Doliny, Kraków 1990, s. 88-201.

${ }^{245}$ A. Wałkówski, Skryptoria cystersów filiacji portyjskiej..., s. 108; tenże, Piśmiennictwo sakralne..., s. 388.

${ }^{246}$ R. Witkowski, Biblioteki klasztorne opactw cysterskich..., s. 156.

${ }^{247}$ H. Kuna, Z dziejów biblioteki OO. Cystersów w Mogile..., s. 48. 
z nauczaniem prawd wiary, formacją duchową i officium divinum. Przewaga takich treści jest typowa dla piśmiennictwa sakralnego cystersów i w ogóle dla średniowiecznych bibliotek klasztornych. Wśród autorów dzieł przeważają pisarze miejscowi, a szczególnie opat P. Hirszberg, brat Mikołaj z Krakowa czy Jakub z Paradyża. Spośród innych autorów wysoką pozycję zajął św. Bernard z Clairvaux. Biblioteka konwentu w Mogile była więc nastawiona na gromadzenie dzieł własnych twórców, natomiast relatywnie wysoki udział św. Bernarda wśród pisarzy spoza klasztoru w Mogile wynikał z jego szczególnych zasług dla całego zakonu cystersów i liczącego się dorobku piśmienniczego. Natomiast obecność św. Tomasza z Akwinu, który nie był cystersem, wiązała się być może z wysoką oceną jego dzieł przez konwent w Mogile.

\section{Streszczenie}

Prezentowany artykuł stanowi fragment obszerniejszych badań nad skryptorium i biblioteką klasztoru cystersów w Mogile do przełomu XV i XVI w. Autorzy wykorzystali ustalenia Edwarda Potkowskiego, zgodnie $\mathrm{z}$ którymi jedną $\mathrm{z}$ form użytkowania pisma $\mathrm{w}$ średniowieczu było zastosowanie go do głoszenia zasad wiary i wyrażania chwały Bożej, czyli do tworzenia piśmiennictwa sakralnego. W jego ramach istnieją bardziej szczegółowe odmiany tematyczne, które autorzy omawiają możliwie dokładnie, wskazując konkretne dzieła i (jeśli jest to możliwe) ich twórców. Granice chronologiczne rozważań zostały wyznaczone przez stan podstawy źródłowej i przemiany kulturowe dotyczące klasztoru cystersów w Mogile. Ograniczenie się do XV stulecia wynika z faktu, że z tego okresu pochodzą wszystkie zachowane średniowieczne kodeksy. Ponadto na przełomie XV i XVI w. zachodziły zmiany związane z upowszechnieniem się druku, co oznaczało schyłek kopiowania ksiąg w skryptorium.

Podstawę źródłową stanowi 20 kodeksów. Z tej liczby autorzy bezpośrednio przebadali 14, ponieważ jedynie te zostały im udostępnione. Pozostałych sześć było niedostępnych z powodu remontu w archiwum klasztornym. Te księgi przebadano za pośrednictwem Katalogu archiwum. Wszystkie kodeksy pochodzą z XV stulecia, lecz tylko dwa z jego pierwszej połowy. Natomiast 11 ksiąg powstało mniej więcej w połowie XV wieku. $Z$ jego drugiego pięćdziesięciolecia pochodzi siedem zachowanych manuskryptów.

Analiza odmian piśmiennictwa sakralnego obecnego w średniowiecznej spuściźnie biblioteki klasztoru cystersów w Mogile wykazała dominację kaznodziejstwa - aż 168 pozycji. Wysoką pozycję zajęły dzieła teologiczne, Biblia z egzegezą oraz m.in. moralistyka i liturgia. Przeważają dzieła doty- 
czące nauczania wiary, formacji duchowej i officium divinum, co było typowe dla księgozbiorów cysterskich i generalnie bibliotek klasztornych wieków średnich. Jeśli chodzi o autorów, to na pierwsze miejsce wysuwają się pisarze należący do konwentu cystersów w Mogile - opat Piotr Hirszberg, brat Mikołaj z Krakowa czy Jakub z Paradyża. Taka sytuacja nie powinna dziwić, ponieważ biblioteka konwentualna $\mathrm{z}$ urzędu była nastawiona na zbieranie dzieł swoich pisarzy. Wśród autorów spoza klasztoru cystersów w Mogile licznie spotykamy teksty pióra św. Bernarda z Clairvaux.

Słowa kluczowe: historia Kościoła - zakony - cystersi - Mogiła - kodykologia - sakralne piśmiennictwo.

\section{Summary}

\section{From the research on sacral writings from medieval library of Cistercian monastery in Mogiła}

Presented article is a part of broader research focused on scriptorium and library of the Cistercians convent in Mogiła till the turn of $15^{\text {th }}$ century. Authors used findings of Edward Potkowski's research according to which one of the form of using writing in medieval times was applying it to implementing principles of faith and expressing God's glory. Within sacral writing there exist differentiated subjects, which are discussed by authors detailed way, indicating specific works and (when it was possible) their authors. Presented research was limited to $15^{\text {th }}$ century due to the fact that 20 preserved medieval codex's stemmed from this period. Authors examined 14 volumes out of the 20, remaining 6 were unavailable due to reconstruction works in convents' archive. They were examined however through the archival catalogue.

In medieval legacy of the Cistercians' convent in Mogiła prevails homiletics (168 texts). The other documents frequently occurring in the disputed collection are theological works, Holy Bible with exegesis and i.e liturgy and moralisation. Dominating works deal with teaching the religion, spiritual formation and officium divinum, what was typical for Cistercians book collections and generally for medieval conventual libraries. When it comes to authors majority of them are the ones belonging to the convent of Mogiła - abbot Piotr Hirszberg, brother Mikołaj from Kraków or Jacobus de Paradiso. Such a situation should not be surprising, because conventual library ex officio was meant to keep the works of their authors. Among the works 
of authors who did not belong to Mogiła convent the most numerous texts are written by St. Bernard of Clairvaux.

Key words: History of the Church - orders - Cistercians - Mogiła - codicology - sacral writings. 